NBER WORKING PAPER SERIES

ASYMMETRIC CRIME CYCLES

H. Naci Mocan

Turan G. Bali

Working Paper 11210

http://www.nber.org/papers/w11210

\author{
NATIONAL BUREAU OF ECONOMIC RESEARCH \\ 1050 Massachusetts Avenue \\ Cambridge, MA 02138 \\ March 2005
}

We thank Norovsambuu Tumennasan, Asia Sikora, Umut Özek and Supadej Ksrisuwan for research assistance and Steve Levitt, Salih Neftçi, Phil Cook, Steve Raphael and Theodore Joyce for helpful comments. An earlier version of this paper was presented at the 2005 American Economic Association Meetings in Philadelphia.The views expressed herein are those of the author(s) and do not necessarily reflect the views of the National Bureau of Economic Research.

(C) 2005 by H. Naci Mocan and Turan G. Bali. All rights reserved. Short sections of text, not to exceed two paragraphs, may be quoted without explicit permission provided that full credit, including $\odot$ notice, is given to the source. 
Asymmetric Crime Cycles

H. Naci Mocan and Turan G. Bali

NBER Working Paper No. 11210

March 2005

JEL No. K4

\begin{abstract}
$\underline{\text { ABSTRACT }}$
Recent theoretical models based on dynamic human capital formation, or social influence, suggest an inverse relationship between criminal activity and economic opportunity and between criminal activity and deterrence, but predict an asymmetric response of crime. In this paper we use three different data sets and three different empirical methodologies to document this previously-unnoticed regularity. Using nonparametric methods we show that the behavior of property crime is asymmetric over time, where increases are sharper but decreases are gradual. Using aggregate time-series U.S. data as well as data from New York City we demonstrate that property crime reacts more (less) strongly to increases (decreases) in the unemployment rate, to decreases (increases) in per capita real GDP and to decreases (increases) in the police force. The same result is obtained between unemployment and property crime in annual state-level panel data. These results suggest that it may be cost effective to implement mechanisms to prevent crime commission rates from rising in the first place.

H. Naci Mocan

Department of Economics

University of Colorado

Campus Box 181; P.O. Box 173364

Denver, CO 80217-3364

and NBER

naci.mocan@cudenver.edu

Turan G. Bali

Department of Economics and Finance

Baruch College

CUNY

17 Lexington Avenue, Box 10-225

New York, NY 10010

turan_bali@baruch.cuny.edu
\end{abstract}




\section{ASYMMETRIC CRIME CYCLES}

\section{Introduction}

Traditional economic models of crime predict an inverse relationship between criminal activity and economic opportunity, and between criminal activity and deterrence. This prediction is obtained from standard static models as well as more recent dynamic ones; and it is confirmed by empirical analyses (Mocan and Rees (forthcoming), Corman and Mocan (2005), Levitt (2002), Gould, Mustard and Weinberg (2002), Freeman and Rodgers (2000), Corman and Mocan (2000), Grogger (1998), and Levitt (1996)). One implicit assumption that prevails in theoretical and empirical work on crime is that the impact on crime of economic conditions (such as unemployment rate) and deterrence (such as the size of the police force) is symmetric. More specifically, it is assumed that if a given improvement in economic conditions reduces criminal activity by a certain amount, an equivalent deterioration in economic conditions would generate an increase in crime by the same absolute value. For example, if the elasticity of crime with respect to the unemployment rate is 0.4 , this would imply that a 10 percent increase in the unemployment rate increases crime by 4 percent. It also implies that a 10 percent decrease in the unemployment rate decreases crime by 4 percent. Same type of symmetry is assumed to hold for crime-deterrence relationship.

In this paper we test whether the response of crime is symmetric to changes in economic conditions and deterrence. The basis for the possibility of asymmetric crime movements can be found in recent theoretical work. Consider, for example, the model of Mocan, Billups and Overland (forthcoming). If an individual engages in criminal activity during an economic downturn, his legal human capital depreciates and his criminal human capital appreciates, which makes it difficult to switch back to the legal sector (or to decrease time spent in crime) after the recession is over. Thus, 
hysteresis in crime is predicted, which implies that the extent of the decrease in crime during economic recovery is expected to be smaller than the increase in crime observed during a downturn: crime is asymmetric over the business cycle. The same asymmetric behavior in crime can be triggered by a change in deterrence: the increase in criminal propensity following a reduction in deterrence will be larger than the decrease in that propensity due to enhanced deterrence because of appreciation of criminal human capital and depreciation of legal human capital during enhanced criminal activity.

In a related, but different framework, Harris and Gonzales Lopez-Valcarcel (2004) formulate a model of information externality in the context of smoking, where a young person, who is uncertain about the costs and benefits of smoking, gathers information about risks and benefits from peers' smoking behavior. This model generates the hypothesis of asymmetric social influence, and suggests that smoking rates may increase quickly but decline sluggishly.

We use aggregate data from the United States and find evidence of asymmetric behavior of criminal activity regarding to the extent of its expansions and contractions. Furthermore, we present evidence that the impact of business cycles on crime is asymmetric. We also present supplemental evidence from New York City on asymmetric crime movements over the business cycle, and over increases and decreases of the police force. Finally, we detect the same asymmetry between crime and unemployment in state-level panel data.

Section II summarizes the theoretical underpinnings that motivate the paper. Section III describes the parametric and nonparametric methods that are applied to test the asymmetry hypothesis. Section IV describes the data. Section V presents the empirical results. Section VI concludes the paper. 


\section{Theoretical Framework of Asymmetry in Crime}

The theoretical foundation of asymmetric behavior in criminal activity can be obtained from a two-stage dynamic stochastic model, where individuals are endowed with legal and criminal human capital (Mocan, Billups and Overland; forthcoming). Potential incomes in legal and criminal sectors depend on the level of the relevant human capital, their rates of return, and random shocks. Both types of human capital can be enhanced by participating in both sectors. Legal human capital can also be enhanced through investment. Each type of human capital is subject to depreciation. Individuals maximize expected discounted lifetime utility, which depends on consumption. The extent of criminal activity and the level of criminal human capital determine the probability of incarceration. If incarcerated, the person goes to prison, where the extent of the punishment is represented by a loss of income. The individual decides in each period on the allocation of time between sectors, and after the realization of income in that period, he decides on the optimal amount of consumption. A particular decision (e.g. the proportion of time allocated to crime) has implications for both future decisions as well as the choices available to the individual in later periods. ${ }^{1}$

Within this framework, during a recession the individual may find it optimal to increase the time allocated to the criminal sector. However, participation in the criminal sector during the recession increases the individual's criminal human capital and depreciates his legal human capital. This decrease in his legal human capital, coupled with the increase in criminal human capital that took place during the recession, makes it difficult to switch back to the legal sector after the recession is over. The criminal trap, or hysteresis in criminal activity emerges because an increase in the extent of criminal activity of the person influences future decisions: the individual is not the

\footnotetext{
${ }^{1}$ The details of the model can be found in Mocan, Billups and Overland (forthcoming).
} 
same person after the recession.

This generates a testable hypothesis. In a recession, where the unemployment rate rises, the property crime rate is expected to increase; but after the recession is over and when the unemployment rate declines, the crime rate will not revert back to its original level as quickly. Put differently, property crime is predicted to exhibit asymmetric behavior over the business cycle. Note that the predicted asymmetry in crime is driven by the individuals' dynamic decisions regarding utility maximization which involves crime-legal work decisions which affect their income. Thus, the hysteresis in crime should be more applicable to property crimes in comparison to violent crimes.

It should be noted that the hysteresis in property crime can also be triggered by noneconomic factors. For example, a number of factors can motivate an individual to increase his participation in the criminal sector. Examples include a decrease in the probability of apprehension due to a reduction in deterrence, a decrease in risk aversion, and a decrease in the severity of punishment. An increased criminal participation following such a change will simultaneously increase the criminal human capital and decrease legal human capital, thereby making the switch back to the legal sector more difficult, which implies that in the aggregate, crime commission rate will increase at a faster rate in comparison to its subsequent decrease.

Harris and Gonzales Lopez-Valcarcel (2004) formulate a learning model of cigarette smoking where each young person gathers information about the risks and benefits of smoking from the behaviors of the peers. The information contained in each peer's behavior is used to update the priors about the benefits (safety, social acceptability, etc.) of smoking. This kind of social interaction within peers (or within the household) generates the possibility that the influence of a peer who is involved in the activity may be different in magnitude from the 
influence of a peer who is not involved in that activity, which yields hysteresis in aggregate behavior.

\section{Empirical Implementation}

\section{A. Non-parametric Analysis}

We first perform a non-parametric analysis to test the asymmetry in the time-series behavior of crime. Following Neftci (1984), consider a time-series $X_{t}$ with $\mathrm{T}+1$ observations. Define a new series $I_{t}$ such that $I_{t}=+1$ if $\Delta X_{t}>0$ and $I_{t}=-1$ if $\Delta X_{t} \leq 0$. Assume that $I_{t}$ can be represented by a stationary second-order Markov process. Let $\lambda_{\mathrm{ij}}(i=0,1 ; j=0,1)$ represent the transition probabilities as follows:

$$
\begin{aligned}
& \lambda_{11}=\operatorname{Pr}\left(I_{t}=1 \mid I_{t-1}=1, I_{t-2}=1\right) \\
& \lambda_{00}=\operatorname{Pr}\left(I_{t}=-1 \mid I_{t-1}=-1, I_{t-2}=-1\right) \\
& \lambda_{10}=\operatorname{Pr}\left(I_{t}=1 \mid I_{t-1}=1, I_{t-2}=-1\right) \\
& \lambda_{01}=\operatorname{Pr}\left(I_{t}=-1 \mid I_{t-1}=-1, I_{t-2}=1\right)
\end{aligned}
$$

If the series $X_{t}$ exhibits sharp increases but gradual decreases, then $\left\{I_{t}\right\}$ remains longer in the state -1 , than in the state +1 . This suggests that the transition probability associated with movements from -1 to -1 will be greater than the transition probability associated with movements from +1 to +1 , which implies that $\lambda_{00}>\lambda_{11}$. On the other hand, if the series is symmetric over the cycle, $\lambda_{00}=\lambda_{11}$. Similarly, as Neftci (1984) indicates, a stronger version of symmetry implies the additional condition that $\lambda_{10}=\lambda_{01}$, which suggests that two consecutive increases followed by one decrease is equally likely as two consecutive decreases followed by an increase. 
Given a realization $S_{T}$ of $\left\{I_{t}\right\}$, the likelihood function can be written as

$$
L\left(S_{T}, \lambda_{i j}, \pi_{0}\right)=\pi_{0}\left(\lambda_{11}\right)^{N_{11}}\left(1-\lambda_{11}\right)^{T_{11}}\left(\lambda_{00}\right)^{N_{00}}\left(1-\lambda_{00}\right)^{T_{00}}\left(\lambda_{01}\right)^{N_{01}}\left(1-\lambda_{01}\right)^{T_{01}}\left(\lambda_{10}\right)^{N_{10}}\left(1-\lambda_{10}\right)^{T_{10}}
$$

where the parameters $N_{11}, T_{11}, N_{00}, \ldots$ represent the number of occurrences in each state implied by transition probabilities, and $\pi_{0}$ is the probability of the initial state. Because the sample we use is not "large" and because the first observation in the sample $(t=1)$ is obviously not the true starting point of $I_{t}$, we follow Neftci (1984), Falk (1986), and Sichel (1989), and parameterize $\pi_{0}$ as a nonlinear function of transition probabilities $\lambda_{\mathrm{ij} .}{ }^{2}$

The investigation of asymmetry in the time-series behavior of the crime rate is performed by maximizing the unrestricted likelihood function in equation (2), and then by maximizing it under the symmetry restriction $\left(\lambda_{00}=\lambda_{11}, \lambda_{10}=\lambda_{01}\right)$. As explained by Neftci (1984), monthly data impose too much noise for this analysis. Imagine that the series is indeed asymmetric with steep increases and gradual decreases. If a white noise series is added to the original series, the runs in -1 will be broken more than the runs in +1 because runs in -1 downward movements have a small derivate. Such a distortion will be less likely with quarterly data as white noise errors are likely to be averaged out.

The empirical analyses are first performed using quarterly U.S. data on property crimes. The hypothesis is that increases in property crime are sharper than the decreases it exhibits over

${ }^{2}$ If the initial state is +1 , and $+1, \pi_{0}=\frac{\left[\left(1-\lambda_{00}\right)\left(\lambda_{10}\right)\right]}{\left[\left(1-\lambda_{11}\right)\left(1-\lambda_{00}+\lambda_{01}\right)\right]+\left[\left(1-\lambda_{00}\right)\left(1-\lambda_{11}+\lambda_{10}\right)\right]}$.

If it is $-1,-1, \pi_{0}=\frac{\left[\left(1-\lambda_{11}\right)\left(\lambda_{01}\right)\right]}{\left[\left(1-\lambda_{00}\right)\left(1-\lambda_{11}+\lambda_{10}\right)\right]+\left[\left(1-\lambda_{11}\right)\left(1-\lambda_{00}+\lambda_{01}\right)\right]}$.

If it is $+1,-1$ or $-1,+1, \pi_{0}=\frac{\left[\left(1-\lambda_{00}\right)\left(\lambda_{01}\right)\right]}{\pi_{00}}$. 
time. To the extent that violent crimes of murder and rape are not motivated by economic conditions, we do not expect to observe an asymmetric behavior in these crimes. We therefore analyze the behavior of murder and rape for comparison to that displayed by property crime. We repeat the analysis with New York City crime data.

\section{B. Parametric Analysis}

Standard static crime models and their dynamic variants postulate a negative relationship between job market opportunities and criminal activity. At the aggregate level, this implies that $\alpha_{1}>0$ in equation (3) below, where $C R_{t}$ stands for the crime rate and $U R_{t}$ represents the unemployment rate. The existing literature provides empirical evidence that the crime level (or crime rate) is indeed positively related to the unemployment rate (Corman and Mocan (2005), Raphael and Winter-Ebmer (2001), Grogger (1998), Cook and Zarkin (1985))

$$
C R_{t}=\alpha_{0}+\alpha_{1} U R_{t}+\varepsilon_{t} .
$$

Note that in equation (3) the implied relationship between $U R$ and $C R$ is symmetric. That is, $\alpha_{1}$ represents the increase in $C R$ in reaction to a given increase in $U R$, which can be viewed as the impact of a recession. At the same time, $\alpha_{1}$ signifies the decrease in crime in response to a decrease in unemployment. This would mean the decline in crime in times of economic recovery. In this standard setting, the impact on crime of an increase in unemployment is postulated to be equal to the impact on crime of a decrease in unemployment.

The theoretical framework summarized in Section II suggests that these impacts are asymmetric. That is, the decrease in crime after the recessions (when the unemployment rate is declining) will not be as large as the increase in crime during a recession. To test this hypothesis, 
we define the crime rate as an asymmetric function of the unemployment rate, where the conditional mean of the crime rate is specified to follow two different paths depending on the change (increase or decrease) in unemployment rate:

$$
C R_{t}=\alpha_{0}+\beta U R_{t}^{+}+\gamma U R_{t}^{-}+\varepsilon_{t}
$$

where

$$
U R_{t}^{+}=\left\{\begin{array}{ll}
U R_{t} & \text { if } U R_{t} \geq U R_{t-1} \\
0 & \text { if } U R_{t}<U R_{t-1}
\end{array}\right\} \text { and } U R_{t}^{-}=\left\{\begin{array}{ll}
U R_{t} & \text { if } U R_{t}<U R_{t-1} \\
0 & \text { if } U R_{t} \geq U R_{t-1}
\end{array}\right\} .
$$

Put differently, $U R_{t}$ can be used to construct two variables $U R_{t}^{+}$and $U R_{t}^{-}$based on the change in $U R_{t}$ between time periods. ${ }^{3}$ A simple example demonstrates the creation of $U R_{t}^{+}$and $U R_{t}^{-}$:

\begin{tabular}{|c|c|c|c|c|c|}
\hline & 1990 & 1991 & 1992 & 1993 & 1994 \\
\hline$U R_{t}$ & 5.6 & 6.8 & 7.5 & 6.9 & 6.1 \\
\hline$U R_{t}^{+}$ & -- & 6.8 & 7.5 & 0 & 0 \\
\hline$U R_{t}^{-}$ & -- & 0 & 0 & 6.9 & 6.1 \\
\hline
\end{tabular}

This implies that

$$
\begin{array}{lll}
E\left(C R_{t}\right)=\alpha_{0}+\beta U R_{t}^{+} & \text {for } & U R_{t}-U R_{t-1} \geq 0 \\
E\left(C R_{t}\right)=\alpha_{0}+\gamma U R_{t}^{-} & \text {for } & U R_{t}-U R_{t-1}<0
\end{array}
$$

We estimate various distributed lag models using monthly U.S. data and test if $\beta=\gamma$. Symmetry is obtained if $\beta=\gamma$ since $U R_{t}^{+}+U R_{t}^{-}=U R_{t}$. We entertain alternative lag-specifications, such as

$$
C R_{t}=\alpha_{0}+\sum_{i=0}^{k} \beta_{i} U R_{t-i}^{+}+\sum_{i=0}^{k} \gamma_{i} U R_{t-i}^{-}+\varepsilon_{t}
$$

\footnotetext{
${ }^{3}$ A similar parametric specification is used by Bali (2000) to test the presence and significance of asymmetry in the conditional mean and conditional volatility of interest rate changes.
} 
and test the hypothesis of symmetric impact of the unemployment rate on crime by investigating whether $\sum_{i=0}^{k} \beta_{i}=\sum_{i=0}^{k} \gamma_{i}$.

For a check of robustness, we repeat the empirical analyses using monthly data from New York City. Because we have monthly police force data from New York City, we also investigate the differential impact of increases and decreases in the police force using the framework of equation (5), where $U R_{t}^{+}$and $U R_{t}^{-}$are replaced by $P O L_{t}^{+}$and $P O L_{t}^{-}$.

Finally, we use state-level annual panel data and investigate whether increases and decreases in state unemployment rates have symmetric impacts on state property and violent crime rates. In this analysis we estimate specifications such as

$$
C R_{i t}=\alpha_{0}+\beta U R_{i t}^{+}+\gamma U R_{i t}^{-}+X_{i t} \Omega+\mu_{i}+\Psi_{t}+\Gamma_{i t}+\varepsilon_{i t}
$$

where $C R_{i t}$ represents property or violent crime in state $i$ for year $t, X_{i t}$ stands for a vector of state characteristics, $\mu_{i}$ represents unobserved state attributes that influence the crime rate, $\Psi_{t}$ stands for year effects, $\Gamma_{i t}$ represents state-specific time trends, and $\varepsilon_{i t}$ is the error term.

\section{Data}

Annual crime data for the Unites States are obtained from the Uniform Crime Reports. The same publication reports the distribution of each crime by month in each year. Using this information, monthly crime values are calculated, separately for burglary, motor-vehicle theft, larceny, murder and rape. The sum of burglary, motor-vehicle theft and larceny gives the property crime. Monthly population figures reported by the Bureau of Economic Analysis are 
used to calculate monthly crime rates (crimes per 100,000 population). Crime rates are seasonally adjusted.

Figure 1 displays the seasonally-adjusted U.S. monthly property crime rate between January 1981 and December 2000. Figures 2 and 3 display the homicide rate and the rape, respectively, for the same time period. Figure 4 presents the seasonally-adjusted monthly unemployment rate obtained from the Bureau of Labor Statistics. Figure 5 shows the seasonallyadjusted monthly growth rate in per capita real GDP, obtained from the Bureau of Economic Analysis. During the period covered by our data, NBER has dated two business cycles. One is from July 1981 to November 1982; the second one is from July 1990 to March 1991. Figures 4 and 5 are consistent with these dates as they display an increase in the unemployment rate and negative income growth, respectively, during these periods.

Figure 6 displays the time-series behavior of property crime in New York City. It consists of burglary, grand larceny theft and motor-vehicle theft. Figures 7 and 8 pertain to murders and rapes in New York City. All data are seasonally adjusted. The crime data are obtained from the Crime Analysis Unit of the New York City Police Department. Figure 9 displays the seasonally-adjusted unemployment rate for New York City, obtained from the Bureau of Labor Statistics. For New York City, crime data are available starting in January 1970. Therefore, in New York City we are able to capture four business cycles, as dated by NBER. More specifically, we also capture the November 1973-March 1975 recession and the January 1980-July 1980 recession, although the latter is short and does not register significantly in New York City unemployment rate (see Figure 9). Figure 10 presents the size of the police force in New York City. 
The third data set we employ in the paper is a state-level panel from 1977 to 2002 . The obvious advantage of this data set is that it allows us to exploit significant state-level variations that exist in crime and unemployment over time, and it allows us to remove the influences of unobserved omitted variables. By including year fixed-effects we control for unobserved factors that impact all the states, and including state fixed-effects and state-specific time trends allows us to control for unobserved differences between states. The data include state-level violent and property crime rates, state unemployment rate, percentage white, black and Hispanic, the age distribution of state population and the proportion of state population in urban areas. Crime data are obtained from the Bureau of Justice Statistics. State population, age representation, ethnic and racial distribution, and urbanization are obtained from the U.S. Department of Commerce, Bureau of the Census.

Augmented Dickey-Fuller (ADF) tests are used to determine the presence of a unit root in time series variables employed in the paper: the property crime rate, murder rate, rape rate, unemployment rate and the per capita growth rate of GDP for the U.S. monthly data covering the period from January 1981 to December 2000, and for property crime, murder, rape, unemployment and police force for New York City monthly data that span the period from January 1970 to April 2000. ${ }^{4}$

The results, which are detailed in Appendix A, provide no evidence for unit root in the U.S. per capita GDP growth, the U.S. property crime rate, and the U.S. unemployment rate. Evidence for a unit root is found for the U.S murder rate and the U.S. rape rate. Therefore, the proper specification of equation (5) is to use level of the U.S. property crime rate and the first-

\footnotetext{
${ }^{4}$ We tested for unit roots and obtained the same results when monthly data were aggregated to quarterly frequency.
} 
difference of the U.S. murder and rape rates as dependent variables. The U.S. unemployment rate and per capita GDP growth rate enter in levels as explanatory variables as they do not contain unit roots.

For the variables pertaining to New York City, the ADF tests revealed that the hypothesis of a unit root cannot be rejected. We employed the Johansen (1988) cointegration test for property crime, murder, rape, the unemployment rate and the police force for NYC. As shown in Appendix B, the likelihood ratio tests strongly reject the null hypothesis of no cointegration. In all cases, we obtained one cointegrating vector for crime (property, murder, or rape) and unemployment, and crime and police. We also tested the presence of cointegration for crime and the two unemployment variables $\left(U R^{+}\right.$and $\left.U R^{-}\right)$and two police variables $\left(P O L^{+}\right.$and $\left.P O L^{-}\right)$ that we employ for tests of asymmetry. In all cases (property, murder, or rape), $U R^{+}, U R^{-}$, $\mathrm{POL}^{+}$and $P O L^{-}$with or without the deterministic trend, we found evidence for one cointegrating vector at the $5 \%$ significance level.

Stock (1987) shows that if the variables are cointegrated, an OLS regression yields a "super-consistent" estimator of the cointegrating parameters because the OLS estimates converge faster than in OLS models using stationary variables. Since crime variables and unemployment, and crime and police are co-integrated for New York City data, equation (5) is run on levels for NYC.

\section{Empirical Results}

\section{A. Nonparametric Analysis}

To investigate whether expansions and contractions in property crime take place at the same rate, we maximized the likelihood function in equation (2) using quarterly U.S. property 
crime rate data. Because the unit root tests revealed stationarity, we employed the data in levels. Table 1 displays the results. The transition parameter $\lambda_{00}$ is estimated to be 0.599 , while $\lambda_{11}$ is 0.494. Similarly, $\lambda_{10}$ and $\lambda_{01}$ are different from each other. The likelihood ratio test rejects the hypothesis of the equality of the transition parameters (symmetry hypothesis) at the $2 \%$ level. This means that the U.S. property crime rate exhibits asymmetry, where the increases are steeper than the declines.

We performed the same exercise for the U.S. murder rate and the U.S. rape rate. Because the Dickey-Fuller tests indicated unit roots in these variables and no unit roots in firstdifferences, to ensure stationarity (see Neftci (1984), Sichel (1989)), these variables are firstdifferenced before estimating the transition parameters. The results, which are also reported in Table 1, show that the hypothesis of symmetry cannot be rejected for these crimes. When we detrended these variables using a Hodrik-Prescott Filter (e.g., Mocan (1999), Blackburn and Morton (1992)), we obtained the same result of symmetry.

These results are indicative of asymmetry in the behavior of U.S. property crime rate, where increases are sharp, but decreases are gradual. On the other hand, rape and murder rates do not exhibit asymmetry in expansions and contractions over time.

\section{B. Parametric Analysis of U.S. Time-Series Data}

Table 2 presents the results of the model where the seasonally-adjusted U.S. monthly property crime rate is regressed on the contemporaneous value and the two lagged values of $U R^{+}$ and the contemporaneous value and the two lagged values of $U R^{-}$. Column (1) displays the point estimate of the sum of the $U R^{+}$coefficients along with robust standard errors. 
The sum of the three $U R^{+}$coefficients is 14.67 , and the hypothesis that it is equal to zero is rejected at the $1 \%$ level. The point estimate indicates that a one percentage-point increase in the unemployment rate increases the property crime rate by 14.67 (per 100,000 people). The mean value of the property crime rate in the sample is about 388 , implying a 3.8 percent increase in the property crime rate. The sum of the coefficients of $U R^{-}$is 11.18 , implying that a one percentage-point decline in the unemployment rate is associated with a decrease in property crime by only 2.9 percent. In column III we report the results of the Wald-test where the hypothesis of the equality of the sum of $U R^{+}$and $U R^{-}$coefficients is tested. The statistic has a $\chi^{2}$ distribution with one degree of freedom. Column III shows that the hypothesis of the equality of the $U R^{+}$and $U R^{-}$coefficients is rejected at the $1 \%$ level.

The mean value of $U R^{+}$is 3.01 and the mean value of $U R^{-}$is 3.45. This indicates that the implied unemployment elasticity of property crime is 0.114 during economic contractions (when unemployment is rising), but the elasticity is 0.097 during expansions (when unemployment is declining).

The coefficients imply that a one-percentage point increase in the unemployment rate is associated with 36,924 additional property crimes (burglaries, motor-vehicles thefts and larceny thefts) per month. On the other hand, a one-percentage point decrease in the unemployment generates only 28,140 fewer burglaries, motor-vehicle thefts and larceny thefts per month.

Panel A of Table 2 demonstrates that the same result is obtained when the lag lengths of the unemployment rate are increased to 4 or 6 . In all cases, the impact of an increase in unemployment, reported in column I, is larger than the impact of a decrease in unemployment, 
reported in column II. Column III shows that the equality of the impact of unemployment during recessions and recoveries is strongly rejected in all specifications.

Panel A also shows that as the lag length of $U R^{+}$and $U R^{-}$increases, their differential impact on property crime gets larger. For example, in the models with 6 lags of the unemployment rates, a one-percentage point increase in the unemployment rate generates 39,227 more property crimes per month, but a one-percentage point decline in the unemployment rates reduces property crimes only by 23,836 per month.

Panels $\mathrm{B}$ and $\mathrm{C}$ of Table 2 display the results for U.S. murder rate and rape rate, respectively. Because these crimes are non-stationary, we employ them in first-difference form. In both cases the impact of the unemployment rate is not statistically significant and the impact of unemployment during a recession is not different from its impact during a recovery.

Table 3 presents the results where the growth rate in per capita real income is used as the indicator of business cycle. The average annual per capita income growth is $2 \%$ in the sample, which implies an average of $0.17 \%$ growth per month. Such an increase in real per capita income generates a decrease in the property crime rate by $5.5(-3272.7 \times 0.0017),(\mathrm{a} 1.4 \%$ decrease in the property crime rate) which translates into 13,648 fewer property crimes per month. On the other hand, a decrease in income by the same absolute magnitude generates an increase in property crime rate by 14 (a 3.7\% increase), which implies 36,070 more property crimes per month. Thus, the impact on property crime of a decrease in per capita GDP growth is much more pronounced than the impact of an increase in per capita GDP growth of the same magnitude. 
Panels $\mathrm{B}$ and $\mathrm{C}$ of Table 3 display the results for U.S. murder rate and rape rate, respectively. Similar to the results obtained from the unemployment rate in Panels B and C of Table 2, these crimes are not influenced by increases or decreases in per capita GDP growth.

The asymmetry in the response of property crime to increases/decreases in the unemployment rate and per capita GDP confirms the prediction of the theory. Note that reverse causality from crime to the unemployment rate or from crime to per capita GDP is not likely in aggregate U.S. data. Local criminal activity may drive away business or may generate relocation of families and therefore may influence unemployment in that locality. However, such reverse causality cannot exist in the U.S. aggregate data. On the other hand, a natural question to ask is whether an unobserved variable influences $U R^{+}$differently from $U R^{-}$to generate biased estimates. A candidate is deterrence, such as the police force. Monthly U.S. police data are not available, but we will investigate this issue with New York data below.

\section{Evidence from New York City Monthly Time-Series Data}

We performed the same analyses using data from New York City using time-series data from January 1970 to April 2000. New York City property crimes, displayed in Figure 6, include grand larceny, motor-vehicle theft and burglary. The economic indicator for New York City, which is available on a monthly basis is the unemployment rate of the City (displayed in Figure 9). Population data for New York City are not available on a monthly basis. ${ }^{5}$

\footnotetext{
${ }^{5}$ The census estimate for NYC population is 7.9 million in 1970, 7.1 million in 1980, 7.3 million in 1990, and 8 million in 2000. Thus, based on census data, NYC population was fairly stable between 1970 and 2000. Because neither monthly nor annual population data are available, interpolation of monthly values from census years would not be sensible. For this reason, and because the size of the population was stable, we followed Corman and Mocan (2000) and Corman and Mocan (2005), and did not deflate crimes by population.
} 
Table 4 displays the results of the non-parametric model for New York City. ${ }^{6}$ In the top panel which shows the results for property crime, $\lambda_{00}$ is estimated to be 0.297 , while $\lambda_{11}$ is 0.275 , but the difference is too small to reject the hypothesis of symmetry. The same is observed for murder and rape crimes in New York City data as well. This may either suggest that crime is symmetric over time in New York City, or that data for New York City may contain a high noise-to-signal ratio to allow for a crisp identification of the transition probabilities.

Table 5 displays the parametric results for New York City. As shown in Panel A of Table 5, a one percentage point increase in NYC unemployment rate generates about 512 additional property crimes per month. On the other hand, a decrease in the unemployment rate has no statistically significant impact on property crime (point estimate is 158.87 with a standard error of 311.6). Column III of Panel A in Table 5 demonstrates that the hypothesis of the equality of $\sum \beta_{i}$ and $\sum \gamma_{i}$ is strongly rejected. This indicates that while an increase in the unemployment rate brings about an increase in property crime, a decrease in unemployment is not associated with a significant reduction in property crime in NYC.

Panels $\mathrm{B}$ and $\mathrm{C}$ of Table 5 display the results for murder and rape for NYC. In case of murder neither an increase $\left(\sum \beta_{i}\right)$, nor a decrease $\left(\sum \gamma_{i}\right)$ in unemployment generates variations in murder. The first row of Panel $\mathrm{C}$, which displays the results for the contemporaneous value and two lags of the unemployment rates for rape, demonstrates that a one-percentage point increase in the seasonally-adjusted unemployment rate brings about 8 additional rapes per month, and a one percentage-point decline in the unemployment rate decreases rapes by about $6 .^{7}$

\footnotetext{
6 As described earlier, quarterly data are used in nonparametric analysis.

${ }^{7}$ Although Corman and Mocan (2005) could not find a significant impact of unemployment on rape, Raphael and Winter-Ebmer (2001) identify a positive relationship between unemployment and rape.
} 
Yet, as can be seen in column III of Panel C, the equality of the impacts during increases and decreases in unemployment cannot be rejected. Put differently, we cannot reject the hypothesis that the impact of unemployment on rape is symmetric.

In Table 6 we report the results pertaining to the impact of police in New York City. The $\beta$ coefficients are related to $\mathrm{POL}^{+}$, i.e., they represent the impact of an increase in police on crime. The $\gamma$ coefficients pertain to $P O L^{-}$variables, and stand for the impact on crime of a decrease in police force. For example, in the first row we observe that a decrease in the size of the police force by one officer increases monthly number of property crimes by 1.975 . On the other hand, adding one more police officer generates a decrease by the amount of 1.878 , and the difference between these two effects is statistically different from zero. This means that the absolute value of the effect of a decrease in police is larger than the corresponding effect of an increase in police, which is consistent with the theory outlined earlier. The results in Panel A of Table 6 imply that deployment of 10 additional police officers would reduce property crimes by about 19 per month, while laying off 10 police officers increases property crimes by about 20-21 in a month. ${ }^{8}$

Panel B of Table 6 displays the results where the dependent variable is monthly homicides in New York City. According to the results, 100 additional police officers reduce murders by about 0.6 per month (or about seven murders per year), and a decrease in the police force by 100 officers increases murders by about 0.7 (or about eight murders per year). However, these impacts are not statistically different from each other, indicating that the impact of police on murder is symmetric.

\footnotetext{
${ }^{8}$ These impacts are greater than what would be normally expected because of the omission of the arrests and because police and arrests are positively correlated. However, the main point here is the asymmetric response of crime to police.
} 
In case of rape, reported in Panel $\mathrm{C}$ of Table 6, police has a statistically significant impact. This result is consistent with the one reported in Corman and Mocan (2005). An increase in police force by 100 officers reduces monthly number of rapes by 1.2, but a decrease by 100 officers increases rapes by 1.4. The difference is statistically significant in two of the three specifications, indicating asymmetric response of this particular crime to variations in deterrence.

\section{Robustness and Model Specification}

We investigated if the results are sensitive to the model specification. For the nonparametric analysis, we investigated if the results were sensitive to the method of detrending. Instead of eliminating nonstationarity using the first-differences, we obtained trend deviations of the variables with unit roots from a Hodrik-Prescott Filter (Mocan 1999, Blackburn and Morton 1992). Alternatively, we eliminated trends by regressing non-stationary variables on linear and quadratic trend terms. The results were insensitive to the method of de-trending.

We estimated the regressions with time-series data using longer lag-lengths, which did not alter the conclusions. We also entertained the possibility that the impact of unemployment on crime might depend on the level of unemployment. We did not reach clear-cut conclusions in this exercise, possibly because the range of the unemployment rate is not wide enough to identify such an impact.

It is also important to investigate if the results may be an artifact of reverse causality or omitted variables. Reverse causality from crime to unemployment is theoretically possible where the unit of observation is a city, but in our particular case, reverse causality is not likely because of high frequency of the data. Specifically, variations in crime in a particular month are 
not likely to impact the unemployment rate in the same month. Furthermore, our time-series models include lagged values of the unemployment rate, which cannot be influenced by contemporaneous variations in crime. Can the differential impact of recessions and recoveries on crime be an artifact of omitted variables? For example, if deterrence is negatively correlated with increases in unemployment, the impact of recession on crime would be overstated given that deterrence has a negative impact on crime. New York City data allow us to investigate the correlations between police and $U R^{+}$and police and $U R^{-}$. The correlations are very small, -0.02 in the former and -0.09 in the latter, indicating that omitted deterrence is not an issue. If there is some other omitted variable which is negatively correlated with recessions but which has a positive impact on crime (such as alcohol consumption), then our results are actually understatements of asymmetric behavior.

\section{E. Evidence from State-level Panel Data}

Our final piece of evidence regarding asymmetric behavior of crime is obtained from a different source of variation. We use annual state-level panel data covering the period from 1977 to 2002. Models are estimated as depicted by Equation (6), where state property crime rate (the sum of burglary, motor-vehicle theft, and larceny theft per 100,000 population) as well as violent

crime rate (the sum of murder, robbery and rape per 100,000 population) are modeled as a function of $U R^{+}$and $U R^{-}$. As before, these variables are created based on changes in state unemployment rates between years.

The results are displayed in Table 7. All specifications include state fixed-effects, year fixed-effects and state-specific time trends. The regressions are estimated with weighted least squares where state populations are used as weights. In column I we report the results where 
property crime rate is explained by $U R^{+}$and $U R^{-}$only (in addition to year and state fixed-effects and state-specific time trends). A one percentage-point increase in state unemployment rate increases the property crime rate by about 103 (the mean of the sample is 4454). This suggests that a one-percentage point increase in the unemployment rate is associated with a $2.3 \%$ increase in property crime rate. On the other hand, a one percentage point decrease in the unemployment rate lowers the property crime rate by only $92(2.06 \%)$. The difference is statistically significant at the 5 percent level, indicating that the extent of the increase in property crime during a particular rise in unemployment is greater than the decrease in property crime when unemployment declines by the same amount. Column II reports the results where the same specification is run with additional controls that may have an influence on state-level criminal activity. A one-percentage point increase in the unemployment rate is associated with an increase in property crime rate by 101, while a one-percentage point decrease in the unemployment rate decreases property crime by only 91 and difference is again statistically significant ( $\mathrm{p}$-value $=0.04)$. These results, once again, indicate that property crime is asymmetric.

Columns III and IV repeat the same exercise for violent crime. As can be seen, the unemployment coefficients are not statistically different from zero, suggesting that no reaction of violent crime to changes in the unemployment rate. When we estimated the models with individual crimes that comprise violent crime, the coefficients of both unemployment variables were insignificant. ${ }^{9}$

\footnotetext{
${ }^{9}$ We also ran the models using the logarithms of violent and property crimes. For violent crimes we obtained small and statistically insignificant impacts of unemployment. For property crimes, the coefficient of $U R^{+}$was 0.0183 , and the one for $U R^{-}$was 0.0155 in the model with no additional controls (the equivalent of column I), and they were 0.0186 and 0.0163 , respectively, in the model with controls (the equivalent of column II). In both cases the difference was statistically significant. It should also be noted that the magnitudes of these effects are very similar to those obtained in previous research, which
} 


\section{Summary and Conclusion}

In this paper we present evidence of a previously-unnoticed regularity of aggregate criminal behavior. Property crime rises quickly but declines gradually over time; and the increase in property crime during economic downturns is greater in magnitude than its decrease in economic recoveries. We use three different data sets and three different estimation methodologies. Using U.S. data, we perform a nonparametric analysis to examine the nature of expansions and contractions over time. Calculation of the transition probabilities shows that for property crime, increases are sharper but decreases are more gradual. This result indicates that property crime expands quickly, but contracts slowly. Murder and rape do not exhibit such asymmetry.

For parametric time-series analyses using aggregate U.S. data, we employ two indicators of aggregate economic activity: the unemployment rate, and per capita growth in real GDP. We find that during an economic downturn, which is associated with an increase in unemployment or a decrease in per capita income growth, property crime rate rises more significantly than the decline it exhibits during a recovery. For murder and rape, no asymmetry is expected due to business cycles, which is confirmed by the data.

We also perform the parametric and nonparametric analyses using data from New York City. Consistent with the U.S. data, we find evidence of asymmetric behavior of property crime, but the hypothesis of symmetry cannot be rejected for murder and rape in New York City, where local unemployment rate is used as a business cycle indicator.

assumed symmetry (e.g. Corman and Mocan (2005), Gould, Mustard and Weinberg (2002), Levitt (2001), Raphael and Winter-Ebmer (2000), and Levitt (1996)). 
The availability of monthly police force information for New York City allows us to investigate the impact of increases and decreases in police on crime. We find that a decrease in the size of the police force has a greater impact on property crimes than an increase in police by an equivalent amount. No such asymmetry is detected for murder, but there is some evidence of persistence of rapes following a decrease in police.

As a final analysis, we use annual state-level panel data from 1997 to 2002 and detect the same regularity. Consistent with the other analyses performed in the paper, we find that a one percentage-point increase in state unemployment rate is associated with a larger absolute increase in crime in comparison to the decline in crime due to a one percentage-point decline in the unemployment rate. Violent crime does not react to variations in state unemployment.

A number of factors may cause an increase in crime such as reduced certainty and severity of punishment, increased joblessness, demographic shifts, changes in risk aversion and time preferences. The results of this paper indicate that persistence in the level of crime will follow after an increase in criminal activity, and crime will not revert back to its original level as quickly as it has risen. Given that the social cost of crime is substantial ${ }^{10}$, the finding of hysteresis in property crime suggests that it may be cost effective to implement measures and mechanisms that will prevent crime commission rates from rising in the first place.

\footnotetext{
${ }^{10}$ The estimates range from $\$ 300$ billion to $\$ 1$ trillion (Miller et al. 1995, Anderson 1999).
} 


\section{References}

Anderson, David A., 1999 “The Aggregate Burden of Crime," Journal of Law and Economics 62, 611-642.

Bali, Turan G., 2000, "Testing the Empirical Performance of Stochastic Volatility Models of the Short Term Interest Rate," Journal of Financial and Quantitative Analysis 35, 191215.

Blackburn, Keith and O. Ravn Morton, 1992, "Business Cycles in the United Kingdom: Facts and Fictions," Economica 59, 383-401.

Cook, Philip J. and Gary A. Zarkin, 1985, “Crime and the Business Cycle,” Journal of Legal Studies 14, 115-28.

Corman, Hope and H. Naci Mocan, 2000, "A Time-Series Analysis of Burglary, Deterrence, and Drug Abuse in New York City,” American Economic Review 90, 584-604.

Corman, Hope and H. Naci Mocan, 2005, "Carrots, Sticks and Broken Windows." Journal of Law and Economics, forthcoming.

Falk, Barry, 1986, "Further Evidence on the Asymmetric Behavior of Economic Time Series over the Business Cycle" Journal of Political Economy 94, 1096-1109.

Freeman, Richard B. and William M. Rodgers III, 2000, "Area Economic Conditions and the Labor Market Outcomes of Young Men in the 1990s Expansion" (In Robert Cherry and William M. Rodgers (eds.), Prosperity for All? The Economic Boom and African Americans. New York: Russell Sage Foundation.)

Gould, Eric D., David B. Mustard and Bruce A. Weinberg, 2002, "Crime Rates and Local Labor Market Opportunities in the United States: 1977-1997," Review of Economics and Statistics 84, 45-61.

Grogger, Jeffrey T., 1998, "Market Wages and Youth Crime", Journal of Labor Economics 16, 756-791.

Harris, E. Jeffrey and Beatriz Gonzales Lopez-Valcarcel, 2004, “Asymmetric Social Interactions in Economics: Cigarette Smoking Among Young People in the United States, 1992-1999," NBER Working Paper No: 10409, April 2004.

Johansen, Soren, 1988, "Statistical Analysis of Cointegration Vectors," Journal of Economic Dynamics and Control 12, 231-254. 
Levitt, Steven D., 2001, “Alternative Strategies for Identifying the Link Between Unemployment and Crime," Journal of Quantitative Criminology 17, 377-90.

Levitt, Steven D., 1996, “The Effect of Prison Population Size on Burglary Rates: Evidence from Prison Overcrowding Litigation," Quarterly Journal of Economics 3, 319-351.

Levitt, Steven D., 2002, "Using Electoral Cycles in Police Hiring to Estimate the Effect of Police on Crime: Reply," American Economic Review 92, 1244-1250.

Miller, Ted R., Mark A. Cohen, and Brian Wiersema, 1995, Crime in the United States: Victim Costs and Consequences, Final Report to the National Institute of Justice.

Mocan, H. Naci, 1999, "Structural Unemployment, Cyclical Unemployment, and Income Inequality," Review of Economics and Statistics 81, 122-135.

Mocan, H. Naci, Steve Billups and Jody Overland, 2005, “A Dynamic Model of Differential Human Capital and Criminal Activity," Economica forthcoming.

Mocan, H. Naci, and Daniel Rees, 2005, "Economic Conditions, Deterrence and Juvenile Crime: Evidence from Micro Data," American Law and Economics Review forthcoming.

Neftçi, Salih N., 1984, "Are Economic Time Series Asymmetric over the Business Cycle?" Journal of Political Economy 92, 307-328.

Raphael, Steven and Rudolf Winter-Ebmer, 2001, "Identifying the Effect of Unemployment on Crime" Journal of Law and Economics 44, 259-283.

Sichel, Daniel E., 1989, “Are Business Cycles Asymmetric?” Journal of Political Economy 97, 1255-1260.

Stock, James, 1987, “Asymptotic Properties of Least-Squares Estimators of Cointegrating Vectors," Econometrica 55, 1035-1056. 
Table 1

Transition Probabilities for the U.S. Crime Rates

\begin{tabular}{|c|c|c|c|c|}
\hline \multicolumn{4}{|c|}{ Property Crime Rate } \\
\hline \multicolumn{2}{|c|}{ Initial Conditions } & & \multicolumn{2}{c|}{ Parameter Estimates } \\
\hline$N_{00}$ & 17 & & $\lambda_{00}$ & $0.599(0.008)$ \\
\hline$T_{00}$ & 12 & & $\lambda_{11}$ & $0.494(0.031)$ \\
\hline$N_{11}$ & 4 & & $\lambda_{10}$ & $0.196(0.008)$ \\
\hline$T_{11}$ & 4 & & & $0.612(0.011)$ \\
\hline$N_{10}$ & 4 & & $\lambda_{01}$ & -49.641 \\
\hline$T_{10}$ & 16 & & $\mathrm{~L}_{\mathrm{R}}$ & -53.644 \\
\hline$N_{01}$ & 12 & & $\chi^{2}(2)$ & $8.006[\mathrm{p}=0.02]$ \\
\hline$T_{01}$ & $-1,-1$ & & \\
\hline Initial State & & & \\
\hline
\end{tabular}

\begin{tabular}{|c|c|c|c|c|}
\hline \multicolumn{4}{|c|}{ Murder Rate } \\
\hline \multicolumn{2}{|c|}{ Initial Conditions } & & \multicolumn{2}{c|}{ Parameter Estimates } \\
\hline$N_{00}$ & 6 & & $\lambda_{00}$ & $0.180(0.011)$ \\
\hline$T_{00}$ & 13 & & $\lambda_{11}$ & $0.311(0.013)$ \\
\hline$N_{11}$ & 2 & & $\lambda_{10}$ & $0.388(0.010)$ \\
\hline$T_{11}$ & 9 & & & $0.604(0.011)$ \\
\hline$N_{10}$ & 9 & & $\lambda_{01}$ & -49.066 \\
\hline$T_{10}$ & 14 & & $\mathrm{~L}_{\mathrm{R}}$ & -50.872 \\
\hline$N_{01}$ & 14 & & $\chi^{2}(2)$ & $3.612[\mathrm{p}=0.16]$ \\
\hline$T_{01}$ & 9 & & & \\
\hline Initial State & $-1,1$ & & \\
\hline
\end{tabular}

\begin{tabular}{|c|c|c|c|c|}
\hline \multicolumn{5}{|c|}{ Rape Rate } \\
\hline \multicolumn{2}{|c|}{ Initial Conditions } & & \multicolumn{2}{|c|}{ Parameter Estimates } \\
\hline$N_{00}$ & 1 & & $\lambda_{00}$ & $0.352(0.013)$ \\
\hline$T_{00}$ & 8 & & $\lambda_{11}$ & $0.123(0.016)$ \\
\hline$N_{11}$ & 5 & & $\lambda_{10}$ & $0.366(0.009)$ \\
\hline$T_{11}$ & 9 & & & $0.293(0.008)$ \\
\hline$N_{10}$ & 10 & & $\lambda_{01}$ & -47.411 \\
\hline$T_{10}$ & 17 & & $\mathrm{~L}_{\mathrm{R}}$ & -47.506 \\
\hline$N_{01}$ & 7 & & & $0.190[\mathrm{p}=0.91]$ \\
\hline$T_{01}$ & 19 & & & \\
\hline Initial State & $-1,-1$ & & \\
\hline
\end{tabular}

$N_{00}: I_{t}=-1, I_{t-1}=-1, I_{t-2}=-1 ; T_{00}: I_{t}=+1, I_{t-1}=-1, I_{t-2}=-1 ; N_{11}: I_{t}=+1, I_{t-1}=+1, I_{t-2}=+1$; $T_{11}: I_{t}=-1, I_{t-1}=+1, I_{t-2}=+1 ; N_{10}: I_{t}=+1, I_{t-1}=+1, I_{t-2}=-1 ; T_{10}: I_{t}=-1, I_{t-1}=+1, I_{t-2}=-1$; $N_{01}: I_{t}=-1, I_{t-1}=-1, I_{t-2}=+1 ; T_{01}: I_{t}=+1, I_{t-1}=-1, I_{t-2}=+1$. The values in (parentheses) are analytical standard errors. The values in [brackets] are the p-values pertaining to the Chi-square test of the equality of the unrestricted and restricted likelihood values $\left(\mathrm{L}_{\mathrm{u}}\right.$ and $\mathrm{L}_{\mathrm{R}}$. 
Table 2

The Impact of the Monthly Unemployment Rate on U.S.

Property Crime Rate

\begin{tabular}{llllc}
\hline & \multicolumn{1}{c}{$\begin{array}{c}\sum \beta \\
\text { (Recession) }\end{array}$} & $\begin{array}{c}\sum \gamma \\
\text { (Recovery) }\end{array}$ & $\sum \beta=\sum \gamma$ \\
\hline \multirow{2}{*}{$\operatorname{Lags}$} & $14.672^{* * *}$ & $11.178^{* * *}$ & $6.513^{* * *}$ \\
& $\operatorname{Lag}(\mathrm{s}) 0$ to 2 & $(1.717)$ & $(1.558)$ & {$[\mathrm{p}=0.011]$} \\
& & $14.811^{* * *}$ & $10.443^{* * *}$ & $5.823^{* * *}$ \\
$\mathrm{~A} \quad \operatorname{Lag}(\mathrm{s})$ 0 to 4 & $(1.896)$ & $(1.603)$ & {$[\mathrm{p}=0.016]$} \\
& & $15.585^{* * *}$ & $9.470^{* * *}$ & $7.448^{* * *}$ \\
& & $(2.092)$ & $(1.654)$ & {$[\mathrm{p}=0.006]$} \\
\hline
\end{tabular}

The Impact of the Monthly Unemployment Rate on U.S.

Murder Rate

\begin{tabular}{|c|c|c|c|c|}
\hline & & $\sum_{(\text {Recession) }} \beta$ & $\sum_{\text {(Recovery) }} \gamma$ & $\sum \beta=\sum \gamma$ \\
\hline \multirow{6}{*}{ B } & \multirow[t]{2}{*}{$\operatorname{Lag}(\mathrm{s}) 0$ to 2} & 0.0002 & -0.001 & 0.637 \\
\hline & & $(0.001)$ & $(0.001)$ & {$[\mathrm{p}=0.425]$} \\
\hline & \multirow[t]{2}{*}{$\operatorname{Lag}(\mathrm{s}) 0$ to 4} & -0.0003 & -0.0003 & 0.0001 \\
\hline & & $(0.002)$ & $(0.002)$ & {$[\mathrm{p}=0.994]$} \\
\hline & \multirow[t]{2}{*}{$\operatorname{Lag}(\mathrm{s}) 0$ to 6} & 0.001 & -0.001 & 0.229 \\
\hline & & $(0.002)$ & $(0.002)$ & {$[\mathrm{p}=0.632]$} \\
\hline
\end{tabular}

The Impact of the Monthly Unemployment Rate on U.S.

Rape Rate

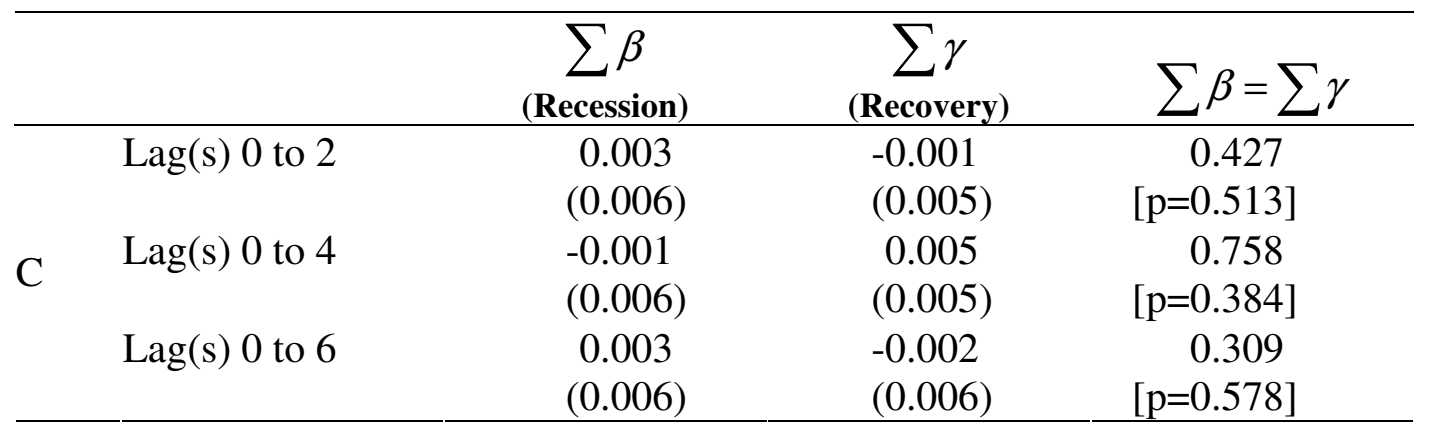

The crime rates and the unemployment rate are seasonally adjusted. Murder and rape rates are in first-differences. Robust standard errors are in (parentheses) under the coefficients. *,**, or *** signify statistical significance at the $10 \%, 5 \%$, and $1 \%$ levels, respectively. The last column reports the Wald-statistic for the hypothesis of the equality of the sums of the $U R^{+}$and $U R^{-}$coefficients. The values in [brackets] contain the p-values for Chi-square (1). 
Table 3

The Impact of Monthly Real Per Capita GDP Growth on U.S.

Property Crime Rate

\begin{tabular}{ccccc}
\hline & \multicolumn{1}{c}{$\begin{array}{c}\sum \beta \\
\text { (Recovery) }\end{array}$} & $\begin{array}{c}\sum \gamma \\
\text { (Recession) }\end{array}$ & $\sum \beta=\sum \gamma$ \\
\hline & Lag(s) 0 to 2 & $-3272.737 * *$ & $-8681.311^{* * *}$ & $3.127 * *$ \\
& & $(1510.404)$ & $(1991.967)$ & {$[\mathrm{p}=0.077]$} \\
& & -2894.781 & $-12453.454 * * *$ & $4.932^{* * *}$ \\
& & $(1978.634)$ & $(2689.956)$ & {$[\mathrm{p}=0.026]$} \\
& $\operatorname{Lag}(\mathrm{s})$ 0 to 4 & -1841.896 & $-16241.750 * * *$ & $7.276^{* * *}$ \\
& & $(2350.230)$ & $(3234.923)$ & {$[\mathrm{p}=0.007]$} \\
\hline
\end{tabular}

The Impact of Monthly Real Per Capita GDP Growth on U.S.

Murder Rate

\begin{tabular}{|c|c|c|c|c|}
\hline & & $\sum_{\text {(Recovery) }} \beta$ & $\sum_{\text {(Recession) }} \gamma$ & $\sum \beta=\sum \gamma$ \\
\hline \multirow{3}{*}{ B } & $\operatorname{Lag}(\mathrm{s}) 0$ to 2 & $\begin{array}{l}-0.007 \\
(0.015)\end{array}$ & $\begin{array}{l}-0.004 \\
(0.021)\end{array}$ & $\begin{array}{c}0.013 \\
{[p=0.908]}\end{array}$ \\
\hline & $\operatorname{Lag}(\mathrm{s}) 0$ to 4 & $\begin{array}{l}-0.008 \\
(0.02)\end{array}$ & $\begin{array}{c}0.010 \\
(0.029)\end{array}$ & $\begin{array}{c}0.178 \\
{[p=0.673]}\end{array}$ \\
\hline & $\operatorname{Lag}(\mathrm{s}) 0$ to 6 & $\begin{array}{l}-0.004 \\
(0.02)\end{array}$ & $\begin{array}{c}0.007 \\
(0.031)\end{array}$ & $\begin{array}{c}0.065 \\
{[p=0.799]}\end{array}$ \\
\hline
\end{tabular}

The Impact of Monthly Real Per Capita GDP Growth on U.S.

Rape Rate

\begin{tabular}{|c|c|c|c|c|}
\hline & & $\sum_{\text {(Recovery) }} \beta$ & $\sum_{(\text {Recession) }} \gamma$ & $\sum \beta=\sum \gamma$ \\
\hline \multirow{3}{*}{$\mathrm{C}$} & $\operatorname{Lag}(\mathrm{s}) 0$ to 2 & $\begin{array}{c}0.006 \\
(0.069)\end{array}$ & $\begin{array}{c}0.029 \\
(0.095)\end{array}$ & $\begin{array}{c}0.028 \\
{[p=0.866]}\end{array}$ \\
\hline & $\operatorname{Lag}(\mathrm{s}) 0$ to 4 & $\begin{array}{c}0.022 \\
(0.074)\end{array}$ & $\begin{array}{c}0.023 \\
(0.102)\end{array}$ & $\begin{array}{r}0.0001 \\
{[p=0.992]}\end{array}$ \\
\hline & $\operatorname{Lag}(\mathrm{s}) 0$ to 6 & $\begin{array}{c}0.01 \\
(0.094)\end{array}$ & $\begin{array}{c}0.044 \\
(0.118)\end{array}$ & $\begin{aligned} & 0.030 \\
{[p=} & 0.863]\end{aligned}$ \\
\hline
\end{tabular}

The crime rates and per capita GDP are seasonally adjusted. Murder and rape rates are in firstdifferences. Robust standard errors are in (parentheses) under the coefficients. *,**, or *** signify statistical significance at the $10 \%, 5 \%$, and $1 \%$ levels, respectively. The last column reports the Wald-statistic for the hypothesis of the equality of the sums of the $U R^{+}$and $U R^{-}$coefficients. The values in [brackets] contain the p-values for Chi-square (1). 
Table 4

Transition Probabilities for New York City Crimes

\begin{tabular}{|c|c|c|c|c|}
\hline \multicolumn{5}{|c|}{ Property Crime } \\
\hline \multicolumn{2}{|c|}{ Initial Conditions } & & \multicolumn{2}{c|}{ Parameter Estimates } \\
\hline$N_{00}$ & 6 & & $\lambda_{00}$ & $0.297(0.010)$ \\
\hline$T_{00}$ & 14 & & $\lambda_{11}$ & $0.275(0.011)$ \\
\hline$N_{11}$ & 5 & & $\lambda_{10}$ & $0.347(0.006)$ \\
\hline$T_{11}$ & 13 & & & $0.356(0.006)$ \\
\hline$N_{10}$ & 14 & & $\mathrm{~L}_{01}$ & -75.306 \\
\hline$T_{10}$ & 25 & & $\mathrm{~L}_{\mathrm{R}}$ & -75.321 \\
\hline$N_{01}$ & 14 & & $\chi^{2}(2)$ & $0.03(\mathrm{p}=0.99)$ \\
\hline$T_{01}$ & 25 & & & \\
\hline Initial State & $-1,1$ & & \\
\hline
\end{tabular}

\begin{tabular}{|c|c|c|c|c|}
\hline \multicolumn{5}{|c|}{ Murder } \\
\hline \multicolumn{2}{|c|}{ Initial Conditions } & & \multicolumn{2}{c|}{ Parameter Estimates } \\
\hline$N_{00}$ & 3 & & $\lambda_{00}$ & $0.198(0.011)$ \\
\hline$T_{00}$ & 12 & & $\lambda_{11}$ & $0.124(0.007)$ \\
\hline$N_{11}$ & 2 & & $\lambda_{10}$ & $0.316(0.005)$ \\
\hline$T_{11}$ & 14 & & & $0.277(0.005)$ \\
\hline$N_{10}$ & 14 & & $\lambda_{01}$ & -67.512 \\
\hline$T_{10}$ & 30 & & $\mathrm{~L}_{\mathrm{R}}$ & -67.753 \\
\hline$N_{01}$ & 12 & & $\chi^{2}(2)$ & $0.482(\mathrm{p}=0.79)$ \\
\hline$T_{01}$ & 31 & & & \\
\hline Initial State & $-1,1$ & & & \\
\hline
\end{tabular}

\begin{tabular}{|c|c|c|c|c|}
\hline \multicolumn{5}{|c|}{ Rape } \\
\hline \multicolumn{2}{|c|}{ Initial Conditions } & & \multicolumn{2}{|c|}{ Parameter Estimates } \\
\hline$N_{00}$ & 1 & & $\lambda_{00}$ & $0.062(0.004)$ \\
\hline$T_{00}$ & 15 & & $\lambda_{11}$ & $0.132(0.008)$ \\
\hline$N_{11}$ & 2 & & $\lambda_{10}$ & $0.300(0.005)$ \\
\hline$T_{11}$ & 13 & & & $0.362(0.005)$ \\
\hline$N_{10}$ & 13 & & $\lambda_{01}$ & -65.829 \\
\hline$T_{10}$ & 30 & & $\mathrm{~L}_{\mathrm{R}}$ & -66.239 \\
\hline$N_{01}$ & 16 & & $\chi^{2}(2)$ & $0.820(\mathrm{p}=0.67)$ \\
\hline$T_{01}$ & 28 & & & \\
\hline Initial State & $1,-1$ & & \\
\hline
\end{tabular}

$N_{00}: I_{t}=-1, I_{t-1}=-1, I_{t-2}=-1 ; T_{00}: I_{t}=+1, I_{t-1}=-1, I_{t-2}=-1 ; N_{11}: I_{t}=+1, I_{t-1}=+1, I_{t-2}=+1$; $T_{11}: I_{t}=-1, I_{t-1}=+1, I_{t-2}=+1 ; N_{10}: I_{t}=+1, I_{t-1}=+1, I_{t-2}=-1 ; T_{10}: I_{t}=-1, I_{t-1}=+1, I_{t-2}=-1$; $N_{01}: I_{t}=-1, I_{t-1}=-1, I_{t-2}=+1 ; T_{01}: I_{t}=+1, I_{t-1}=-1, I_{t-2}=+1$. The values in (parentheses) are analytical standard errors. The values in [brackets] are the p-values pertaining to the Chi-square test of the equality of the unrestricted and restricted likelihood values $\left(\mathrm{L}_{\mathrm{u}}\right.$ and $\mathrm{L}_{\mathrm{R}}$. 
Table 5

The Impact of the Monthly Unemployment Rate on New York City Property Crimes

\begin{tabular}{|c|c|c|c|c|}
\hline & & $\sum_{(\text {Recession) }} \beta$ & $\sum_{(\text {Recovery })} \gamma$ & $\sum \beta=\sum \gamma$ \\
\hline \multirow{3}{*}{ A } & $\operatorname{Lag}(\mathrm{s}) 0$ to 2 & $\begin{array}{c}511.634^{*} \\
(306.702)\end{array}$ & $\begin{array}{l}158.87 \\
(311.585)\end{array}$ & $\begin{array}{r}3.093^{*} \\
{[\mathrm{p}=0.079]}\end{array}$ \\
\hline & $\operatorname{Lag}(\mathrm{s}) 0$ to 4 & $\begin{array}{l}557.549 * \\
(325.159)\end{array}$ & $\begin{array}{c}6.497 \\
(343.956)\end{array}$ & $\begin{array}{r}3.498^{*} \\
{[\mathrm{p}=0.061]}\end{array}$ \\
\hline & $\operatorname{Lag}(\mathrm{s}) 0$ to 6 & $\begin{array}{l}586.742 * \\
(341.965)\end{array}$ & $\begin{array}{c}-96.061 \\
(369.798)\end{array}$ & $\begin{array}{c}3.77 * \\
{[p=0.052]}\end{array}$ \\
\hline
\end{tabular}

The Impact of the Monthly Unemployment Rate on New York City Murders

\begin{tabular}{|c|c|c|c|c|}
\hline & & $\sum_{\text {(Recession) }} \beta$ & $\sum_{(\text {Recovery })} \gamma$ & $\sum \beta=\sum \gamma$ \\
\hline \multirow{3}{*}{ B } & $\operatorname{Lag}(\mathrm{s}) 0$ to 2 & $\begin{array}{c}2.343 \\
(1.697)\end{array}$ & $\begin{array}{c}1.038 \\
(1.819)\end{array}$ & $\begin{array}{c}1.094 \\
{[p=0.295]}\end{array}$ \\
\hline & $\operatorname{Lag}(\mathrm{s}) 0$ to 4 & $\begin{array}{c}2.494 \\
(1.811)\end{array}$ & $\begin{array}{l}-0.298 \\
(1.987)\end{array}$ & $\begin{array}{c}2.407 \\
{[p=0.121]}\end{array}$ \\
\hline & $\operatorname{Lag}(\mathrm{s}) 0$ to 6 & $\begin{array}{l}1.96 \\
(1.877)\end{array}$ & $\begin{array}{l}-1.308 \\
(2.146)\end{array}$ & $\begin{array}{c}2.313 \\
{[p=0.128]}\end{array}$ \\
\hline
\end{tabular}

The Impact of the Monthly Unemployment Rate on New York City Rapes

\begin{tabular}{|c|c|c|c|c|}
\hline & & $\sum_{(\text {Recession) }} \beta$ & $\sum_{\text {(Recovery) }} \gamma$ & $\sum \beta=\sum \gamma$ \\
\hline \multirow{3}{*}{$\mathrm{C}$} & $\operatorname{Lag}(\mathrm{s}) 0$ to 2 & $\begin{array}{l}8.048 * * \\
(3.197)\end{array}$ & $\begin{array}{l}5.997 * \\
(3.18)\end{array}$ & $\begin{array}{c}0.922 \\
{[\mathrm{p}=0.337]}\end{array}$ \\
\hline & $\operatorname{Lag}(\mathrm{s}) 0$ to 4 & $\begin{array}{l}7.57 * * \\
(3.365)\end{array}$ & $\begin{array}{c}5.514 \\
(3.429)\end{array}$ & $\begin{array}{c}0.431 \\
{[p=0.512]}\end{array}$ \\
\hline & $\operatorname{Lag}(\mathrm{s}) 0$ to 6 & $\begin{array}{l}7.435^{* *} \\
(3.576)\end{array}$ & $\begin{array}{c}4.315 \\
(3.56)\end{array}$ & $\begin{array}{c}0.637 \\
{[p=0.425]}\end{array}$ \\
\hline
\end{tabular}

The crime rates and the unemployment rate are seasonally adjusted. All variables are in levels. Robust standard errors are in (parentheses) under the coefficients. *, **, or *** signify statistical significance at the $10 \%, 5 \%$, and $1 \%$ levels, respectively. The last column reports the Wald-statistic for the hypothesis of the equality of the sums of the $U R^{+}$and $U R^{-}$ coefficients. The values in [brackets] contain the p-values for Chi-square (1). 
Table 6

The Impact of the Monthly Police Force on New York City Property Crimes

\begin{tabular}{|c|c|c|c|c|}
\hline & & $\sum_{\text {(Increase in police) }}$ & $\sum_{\text {(Decrease in police) }}$ & $\sum \beta=\sum \gamma$ \\
\hline \multirow{3}{*}{ A } & $\operatorname{Lag}(\mathrm{s}) 0$ to 2 & $\begin{array}{l}-1.878 * * * \\
(0.056)\end{array}$ & $\begin{array}{l}-1.975 * * * \\
(0.053)\end{array}$ & $\begin{aligned} & 4.224^{* *} \\
{[\mathrm{p}=} & 0.04]\end{aligned}$ \\
\hline & $\operatorname{Lag}(\mathrm{s}) 0$ to 4 & $\begin{array}{l}-1.879 * * * \\
(0.058)\end{array}$ & $\begin{array}{l}-2.039 * * * \\
(0.053)\end{array}$ & $\begin{array}{l}4.728^{* *} \\
{[\mathrm{p}=0.03]}\end{array}$ \\
\hline & $\operatorname{Lag}(\mathrm{s}) 0$ to 6 & $\begin{array}{l}-1.881 * * * \\
(0.059)\end{array}$ & $\begin{array}{l}-2.091 * * * \\
(0.055)\end{array}$ & $\begin{array}{l}5.258^{* *} \\
{[\mathrm{p}=0.02]}\end{array}$ \\
\hline
\end{tabular}

The Impact of the Monthly Police Force on New York City Murders

\begin{tabular}{|c|c|c|c|c|}
\hline & & $\sum_{\text {(Increase in police) }}$ & $\sum_{\text {(Decrease in police) }}$ & $\sum \beta=\sum \gamma$ \\
\hline \multirow{3}{*}{ B } & $\operatorname{Lag}(\mathrm{s}) 0$ to 2 & $\begin{array}{l}-0.006 * * * \\
(0.0004)\end{array}$ & $\begin{array}{l}-0.007 * * * \\
(0.0005)\end{array}$ & $\begin{array}{r}0.589 \\
{[p=0.44]}\end{array}$ \\
\hline & $\operatorname{Lag}(\mathrm{s}) 0$ to 4 & $\begin{array}{l}-0.0062 * * * \\
(0.0004)\end{array}$ & $\begin{array}{l}-0.0068 * * * \\
(0.0005)\end{array}$ & $\begin{array}{r}1.747 \\
{[p=0.19]}\end{array}$ \\
\hline & $\operatorname{Lag}(\mathrm{s}) 0$ to 6 & $\begin{array}{l}-0.0063 * * * \\
(0.0004)\end{array}$ & $\begin{array}{l}-0.0068 * * * \\
(0.0005)\end{array}$ & $\begin{array}{r}0.883 \\
{[\mathrm{p}=0.35]}\end{array}$ \\
\hline
\end{tabular}

The Impact of the Monthly Police Force on New York City Rapes

\begin{tabular}{|c|c|c|c|c|}
\hline & & $\sum_{\text {(Increase in police) }} \beta$ & $\sum_{\text {(Decrease in police) }}$ & $\sum \beta=\sum \gamma$ \\
\hline \multirow{6}{*}{$\mathrm{C}$} & \multirow[t]{2}{*}{$\operatorname{Lag}(\mathrm{s}) 0$ to 2} & $-0.012 * * *$ & $-0.013 * * *$ & 1.801 \\
\hline & & $(0.0007)$ & $(0.0007)$ & {$[\mathrm{p}=0.18]$} \\
\hline & \multirow[t]{2}{*}{$\operatorname{Lag}(\mathrm{s}) 0$ to 4} & $-0.012 * * *$ & $-0.014 * * *$ & $3.512 *$ \\
\hline & & $(0.0007)$ & $(0.0007)$ & {$[\mathrm{p}=0.06]$} \\
\hline & \multirow[t]{2}{*}{$\operatorname{Lag}(\mathrm{s}) 0$ to 6} & $-0.011 * * *$ & $-0.014 * * *$ & $5.676 * *$ \\
\hline & & $(0.0007)$ & $(0.0007)$ & {$[\mathrm{p}=0.02]$} \\
\hline
\end{tabular}

The crime rates and the police force are seasonally adjusted. All variables are in levels. Robust standard errors are in (parentheses) under the coefficients. $\beta$ s represent coefficients of $\mathrm{POL}^{+}, \gamma \mathrm{s}$ represent coefficients of $\mathrm{POL}^{-}$. *, **, or *** signify statistical significance at the $10 \%, 5 \%$, and $1 \%$ levels, respectively. The last column reports the Wald-statistic for the hypothesis of the equality of the sums of the $\mathrm{POL}^{+}$and $\mathrm{POL}^{-}$coefficients. The values in [brackets] contain the p-values for Chi-square (1). 
Table 7

The Impact of Recessions and Recoveries on Crime Using State-level Panel Data

\begin{tabular}{|c|c|c|c|c|}
\hline & \multicolumn{2}{|c|}{ Property Crime Rate } & \multicolumn{2}{|c|}{ Violent Crime Rate } \\
\hline & (I) & (II) & (III) & (IV) \\
\hline Recession $\left(U R^{+}\right)$ & $\begin{array}{l}102.821 * * * \\
(18.194)\end{array}$ & $\begin{array}{l}101.419 * * * \\
(18.507)\end{array}$ & $\begin{array}{c}3.065 \\
(1.926)\end{array}$ & $\begin{array}{c}0.400 \\
(1.626)\end{array}$ \\
\hline Recovery $\left(U R^{-}\right)$ & $\begin{array}{l}91.868 * * * \\
(20.530)\end{array}$ & $\begin{array}{l}91.092 * * * \\
(20.640)\end{array}$ & $\begin{array}{c}0.757 \\
(2.020)\end{array}$ & $\begin{array}{l}-1.819 \\
(1.806)\end{array}$ \\
\hline$\%$ White & & $\begin{array}{l}-897.372 * * \\
(429.776)\end{array}$ & & $\begin{array}{c}-127.175 * * * \\
(36.844)\end{array}$ \\
\hline$\%$ Black & & $\begin{array}{c}807.706 \\
(819.278)\end{array}$ & & $\begin{array}{l}-75.784 \\
(92.325)\end{array}$ \\
\hline$\%$ Hispanic & & $\begin{array}{l}-4198.167 * * * \\
(1487.621)\end{array}$ & & $\begin{array}{c}-35.309 \\
(131.806)\end{array}$ \\
\hline \% Urban Pop. & & $\begin{array}{l}-1393.803 \\
(1364.396)\end{array}$ & & $\begin{array}{c}91.461 \\
(165.775)\end{array}$ \\
\hline$\%$ 15-19 year olds & & $\begin{array}{l}375.158 * * * \\
(71.563)\end{array}$ & & $\begin{array}{l}26.21 * * * \\
(7.740)\end{array}$ \\
\hline$\%$ 20-24 year olds & & $\begin{array}{c}-128.338 * * * \\
(47.306)\end{array}$ & & $\begin{array}{c}5.778 \\
(5.427)\end{array}$ \\
\hline$\%$ 25-34 year olds & & $\begin{array}{l}191.275^{* *} \\
(29.074)\end{array}$ & & $\begin{array}{l}19.386^{* * * *} \\
(2.777)\end{array}$ \\
\hline$\%$ 35-44 year olds & & $\begin{array}{c}-205.607 * * * \\
(51.311)\end{array}$ & & $\begin{array}{c}-37.756^{* * *} \\
(5.577)\end{array}$ \\
\hline$\%$ 45-54 year olds & & $\begin{array}{c}159.436 \\
(118.563)\end{array}$ & & $\begin{array}{c}1.291 \\
(5.806)\end{array}$ \\
\hline State Dummies & Yes & Yes & Yes & Yes \\
\hline Year Dummies & Yes & Yes & Yes & Yes \\
\hline State Trends & Yes & Yes & Yes & Yes \\
\hline $\mathrm{N}$ & 1,275 & 1,275 & 1,275 & 1,275 \\
\hline
\end{tabular}

The numbers in parentheses are clustered standard errors that correct for heteroscedasticity and contemporaneous cross-correlations in the residuals. *,**, or *** signify statistical significance at the $10 \%, 5 \%$, and $1 \%$ levels, respectively. 


\section{Appendix A: Unit Root Tests}

Augmented Dickey Fuller Unit Root Test Results for the U.S. monthly Data

\begin{tabular}{ccccc}
\hline & ADF statistic & $1 \%$ critical & $5 \%$ critical & $10 \%$ critical \\
\hline Property Crime Rate & $-2.9743^{* * *}$ & -2.5742 & -1.9410 & -1.6164 \\
\hline Murder Rate & -0.4009 & -3.4595 & -2.8739 & -2.5733 \\
\hline Rape Rate & -0.5299 & -4.0005 & -3.4303 & -3.1384 \\
\hline Murder Rate $1^{\text {st }}$ Difference & $-12.956^{* * *}$ & -3.4595 & -2.8739 & -2.5733 \\
\hline Rape Rate $1^{\text {st }}$ Difference & $-11.192^{* * *}$ & -4.0002 & -3.4301 & -3.1383 \\
\hline Unemployment Rate & $-3.6734^{* *}$ & -4.0005 & -3.4303 & -3.1384 \\
\hline Per Capita Real GDP Growth & $-3.5025^{* * *}$ & -3.4598 & -2.8740 & -2.5733 \\
\hline
\end{tabular}

Augmented Dickey Fuller Unit Root Test Results for NYC monthly Data

\begin{tabular}{ccccc}
\hline & ADF statistic & $1 \%$ critical & $5 \%$ critical & $10 \%$ critical \\
\hline Property Crime & -0.7100 & -3.9873 & -3.4239 & -3.1347 \\
\hline Murder & -1.5108 & -3.9876 & -3.4241 & -3.1347 \\
\hline Rape & -0.5089 & -2.5713 & -1.9404 & -1.6161 \\
\hline Unemployment Rate & -2.4134 & -3.9873 & -3.4239 & -3.1347 \\
\hline Police & -1.1128 & -3.9874 & -3.4240 & -3.1347 \\
\hline Property Crime $1^{\text {st }}$ Difference & $-12.288^{* * *}$ & -3.9874 & -3.4240 & -3.1347 \\
\hline Murder $1^{\text {st }}$ Difference & $-12.023^{* * *}$ & -3.9876 & -3.4241 & -3.1348 \\
\hline Rape $1^{\text {st }}$ Difference & $-11.590^{* * *}$ & -3.9876 & -3.4241 & -3.1348 \\
\hline Unemployment $1^{\text {st }}$ Difference & $-10.933^{* * *}$ & -3.9874 & -3.4240 & -3.1347 \\
\hline Police $1^{\text {st }}$ Difference & $-10.120^{* * *}$ & -3.9875 & -3.4240 & -3.1347 \\
\hline
\end{tabular}

Augmented Dickey Fuller (ADF) test statistics and the MacKinnon critical values for rejection of hypothesis of a unit root are presented. ${ }^{* * *},{ }^{* *},{ }^{*}$ indicate statistical significance at the $1 \%, 5 \%$, and $10 \%$ level, respectively. 


\section{Appendix B. Cointegration Test Results for NYC Monthly Data}

Property Crime \& Unemployment

\begin{tabular}{ccccc}
\hline Eigenvalue & $\begin{array}{c}\text { Likelihood } \\
\text { Ratio }\end{array}$ & $\begin{array}{c}\text { 5 Percent } \\
\text { Critical Value }\end{array}$ & $\begin{array}{c}\text { 1 Percent } \\
\text { Critical Value }\end{array}$ & $\begin{array}{c}\text { Hypothesized } \\
\text { No. of CE(s) }\end{array}$ \\
\hline 0.166117 & 74.49 & 29.68 & 35.65 & None $^{* *}$ \\
0.024658 & 9.45 & 15.41 & 20.04 & At most 1 \\
0.001432 & 0.51 & 3.76 & 6.65 & At most 2 \\
\hline
\end{tabular}

Murder \& Unemployment

\begin{tabular}{ccccc}
\hline Eigenvalue & $\begin{array}{c}\text { Likelihood } \\
\text { Ratio }\end{array}$ & $\begin{array}{c}\text { 5 Percent } \\
\text { Critical Value }\end{array}$ & $\begin{array}{c}\text { 1 Percent } \\
\text { Critical Value }\end{array}$ & $\begin{array}{c}\text { Hypothesized } \\
\text { No. of CE(s) }\end{array}$ \\
\hline 0.166941 & 78.48 & 29.68 & 35.65 & None $^{\star *}$ \\
0.023703 & 13.09 & 15.41 & 20.04 & At most 1 \\
0.012488 & 4.50 & 3.76 & 6.65 & At most $2^{*}$ \\
\hline
\end{tabular}

Rape \& Unemployment

\begin{tabular}{ccccc}
\hline Eigenvalue & $\begin{array}{c}\text { Likelihood } \\
\text { Ratio }\end{array}$ & $\begin{array}{c}\text { 5 Percent } \\
\text { Critical Value }\end{array}$ & $\begin{array}{c}\text { 1 Percent } \\
\text { Critical Value }\end{array}$ & $\begin{array}{c}\text { Hypothesized } \\
\text { No. of CE(s) }\end{array}$ \\
\hline 0.172255 & 78.23 & 29.68 & 35.65 & None $^{* *}$ \\
0.019562 & 10.55 & 15.41 & 20.04 & At most 1 \\
0.009676 & 3.48 & 3.76 & 6.65 & At most 2 \\
\hline
\end{tabular}

Property Crime \& Police

\begin{tabular}{ccccc}
\hline Eigenvalue & $\begin{array}{c}\text { Likelihood } \\
\text { Ratio }\end{array}$ & $\begin{array}{c}\text { 5 Percent } \\
\text { Critical Value }\end{array}$ & $\begin{array}{c}\text { 1 Percent } \\
\text { Critical Value }\end{array}$ & $\begin{array}{c}\text { Hypothesized } \\
\text { No. of CE(s) }\end{array}$ \\
\hline 0.186896 & 88.70 & 29.68 & 35.65 & None $^{* *}$ \\
0.038698 & 14.63 & 15.41 & 20.04 & At most 1 \\
0.001411 & 0.51 & 3.76 & 6.65 & At most 2 \\
\hline
\end{tabular}

Murder \& Police

\begin{tabular}{ccccc}
\hline Eigenvalue & $\begin{array}{c}\text { Likelihood } \\
\text { Ratio }\end{array}$ & $\begin{array}{c}\text { 5 Percent } \\
\text { Critical Value }\end{array}$ & $\begin{array}{c}\text { 1 Percent } \\
\text { Critical Value }\end{array}$ & $\begin{array}{c}\text { Hypothesized } \\
\text { No. of CE }(\mathrm{s})\end{array}$ \\
\hline 0.180735 & 78.64 & 29.68 & 35.65 & None ** \\
0.019946 & 7.27 & 15.41 & 20.04 & At most 1 \\
0.000152 & 0.05 & 3.76 & 6.65 & At most 2 \\
\hline
\end{tabular}




\begin{tabular}{ccccc}
\multicolumn{5}{c}{ Rape \& Police } \\
\hline Eigenvalue & Rikelihood & 5 Percent & 1 Percent & Hypothesized \\
Critical Value & Critical Value & No. of CE(s) \\
\hline 0.195115 & 94.15 & 29.68 & 35.65 & None $^{* *}$ \\
0.044850 & 16.44 & 15.41 & 20.04 & At most $1^{*}$ \\
0.000035 & 0.01 & 3.76 & 6.65 & At most 2 \\
\hline
\end{tabular}

Johansen (1987) cointegration test results are presented for NYC data. The likelihood ratio test statistics indicate 1 cointegrating equation at the 5\% significance level for crime (property, murder, rape) and unemployment rate. 
Figure 1

U.S. Property Crime Rate (Seasonally Adjusted)

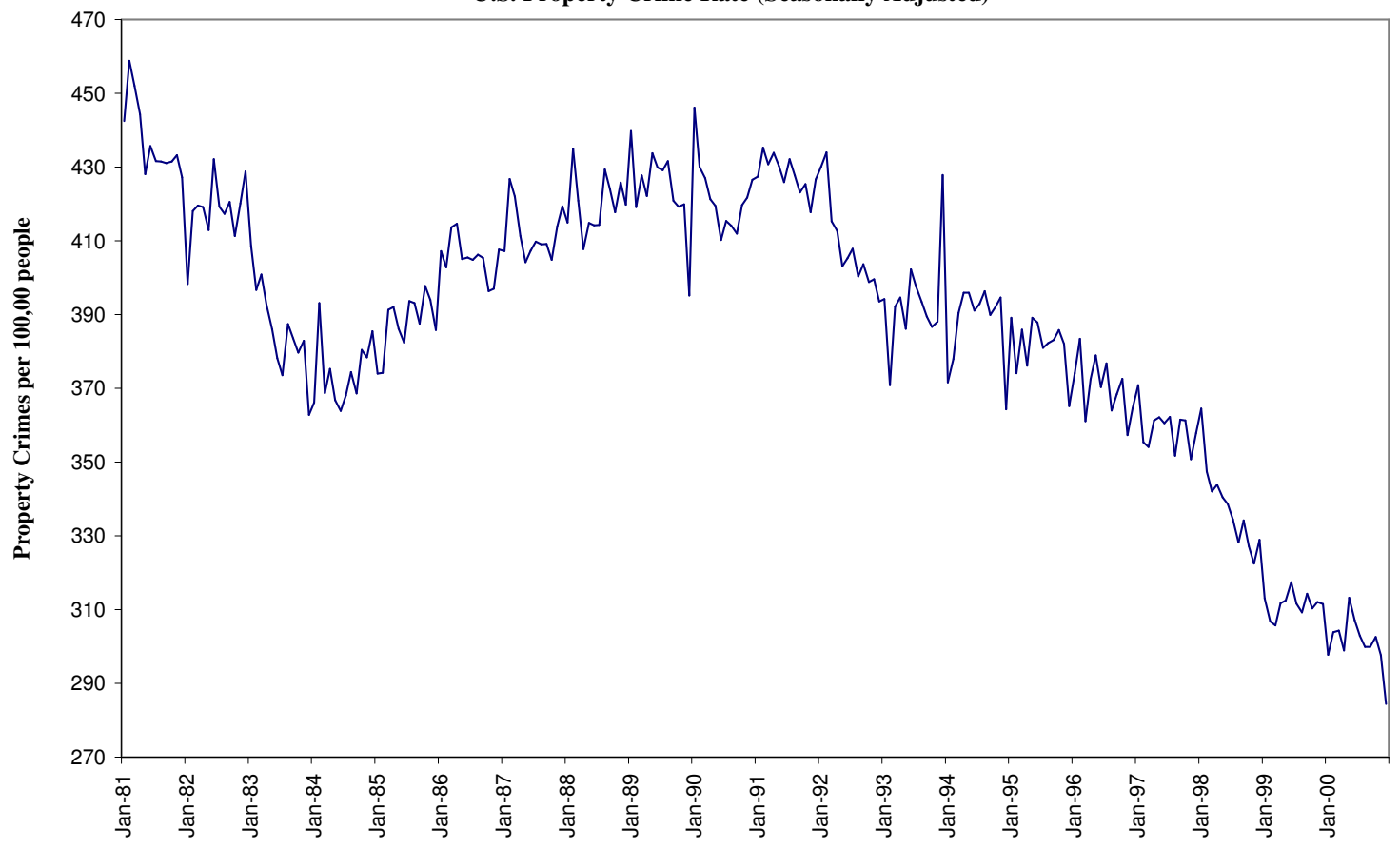

Figure 2

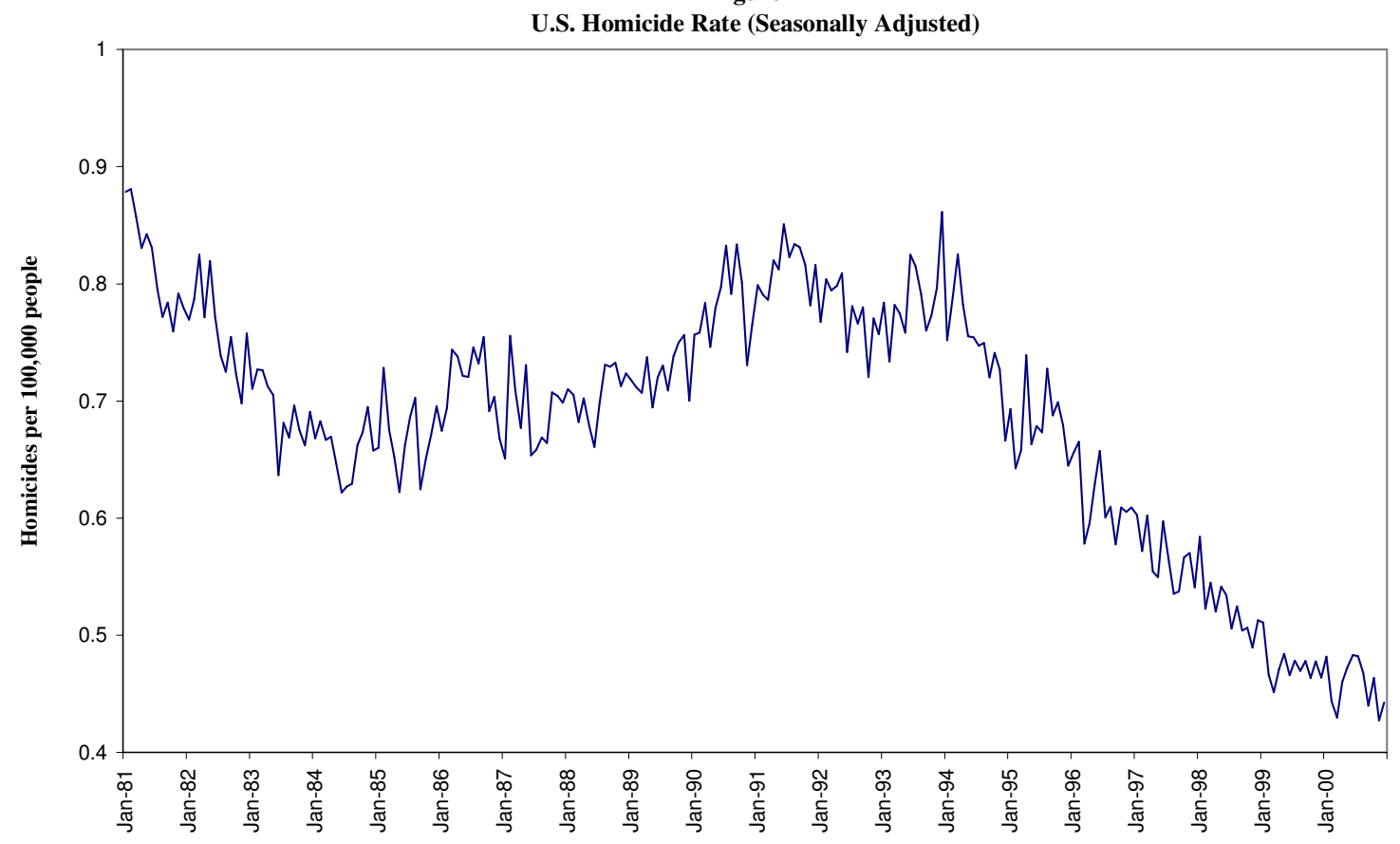




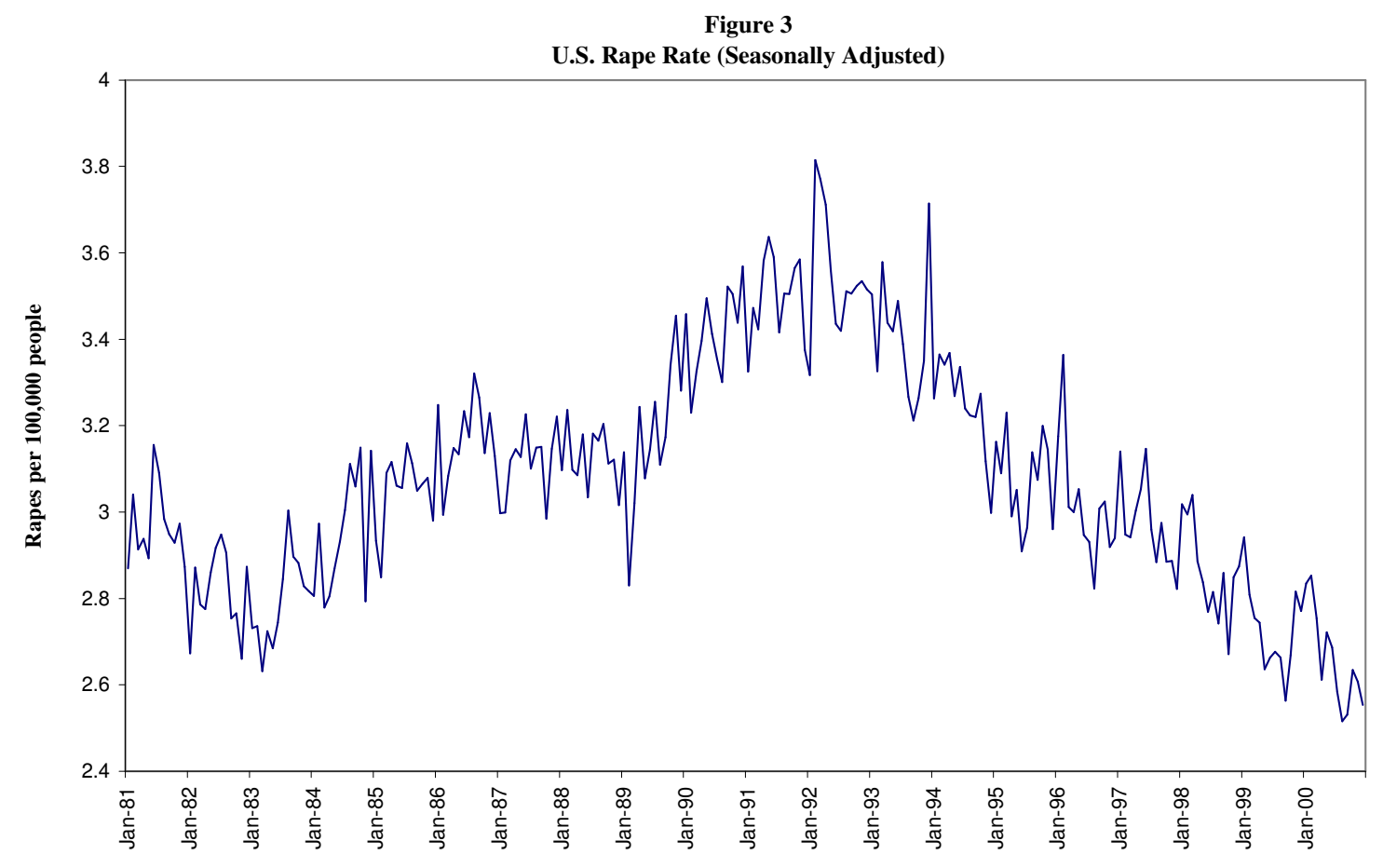

Figure 4

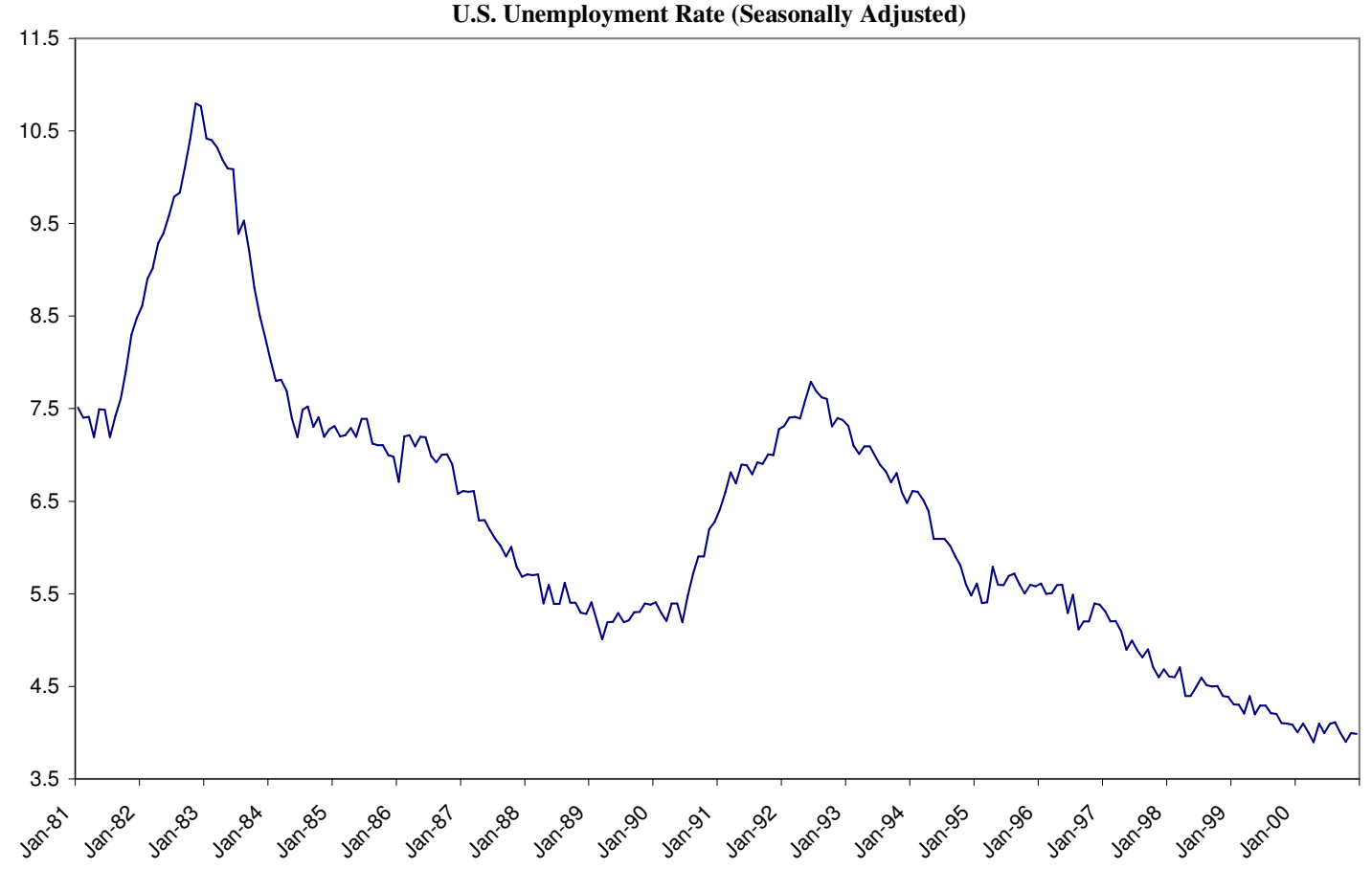


Figure 5

U.S. GDP Growth (Seasonally Adjusted)

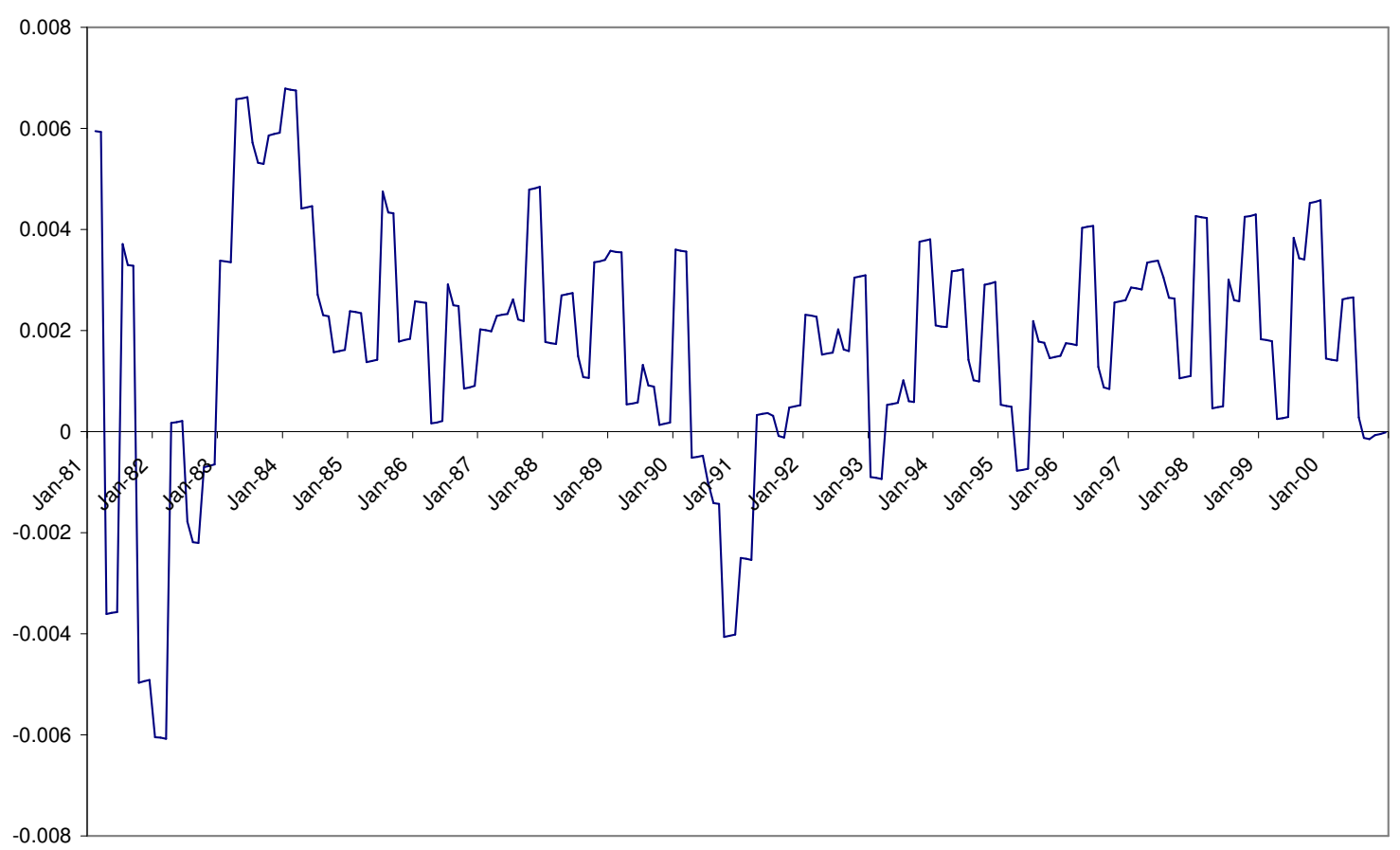

Figure 6

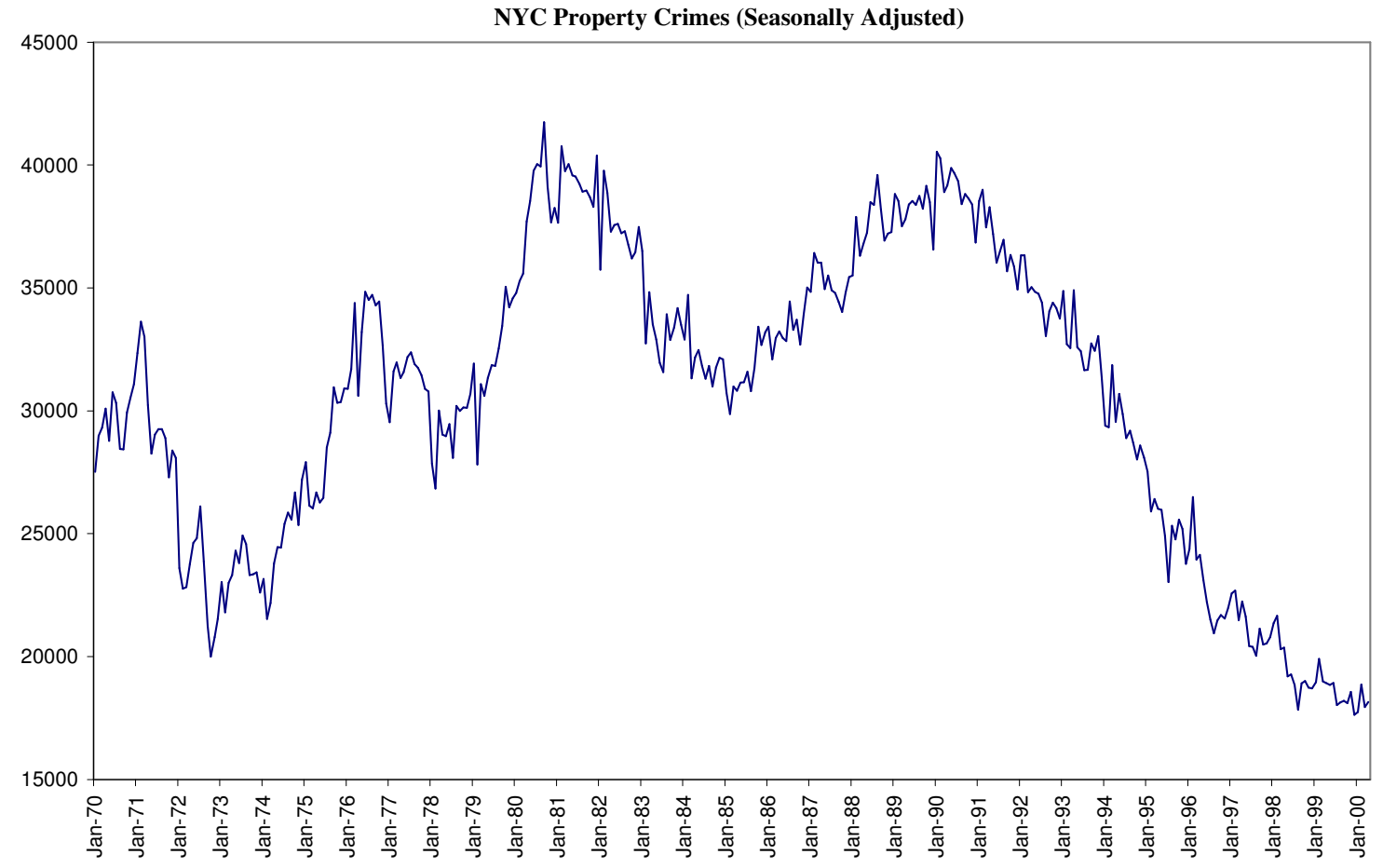


Figure 7

NYC Homicides (Seasonally Adjusted)

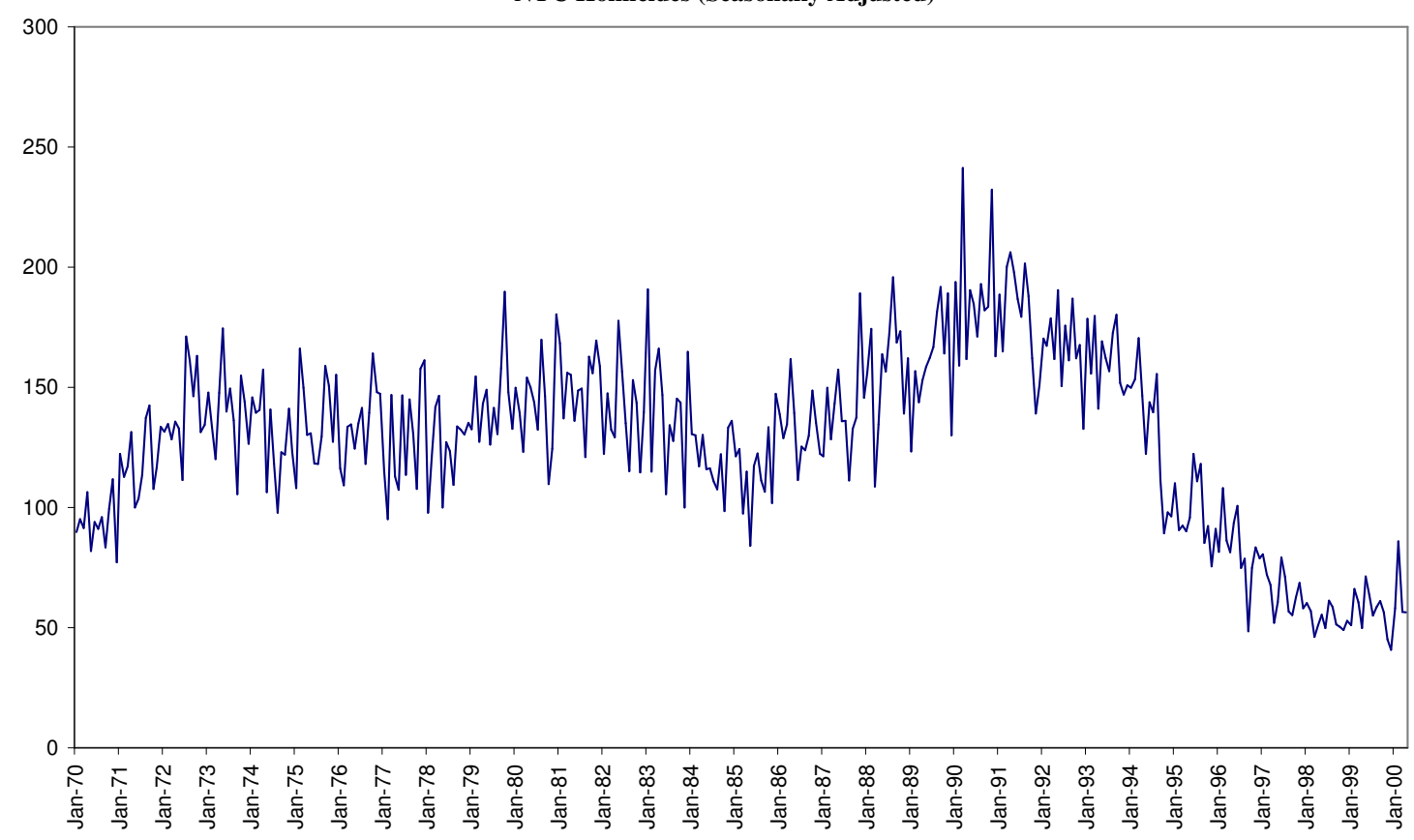

Figure 8

NYC Rapes (Seasonally Adjusted)

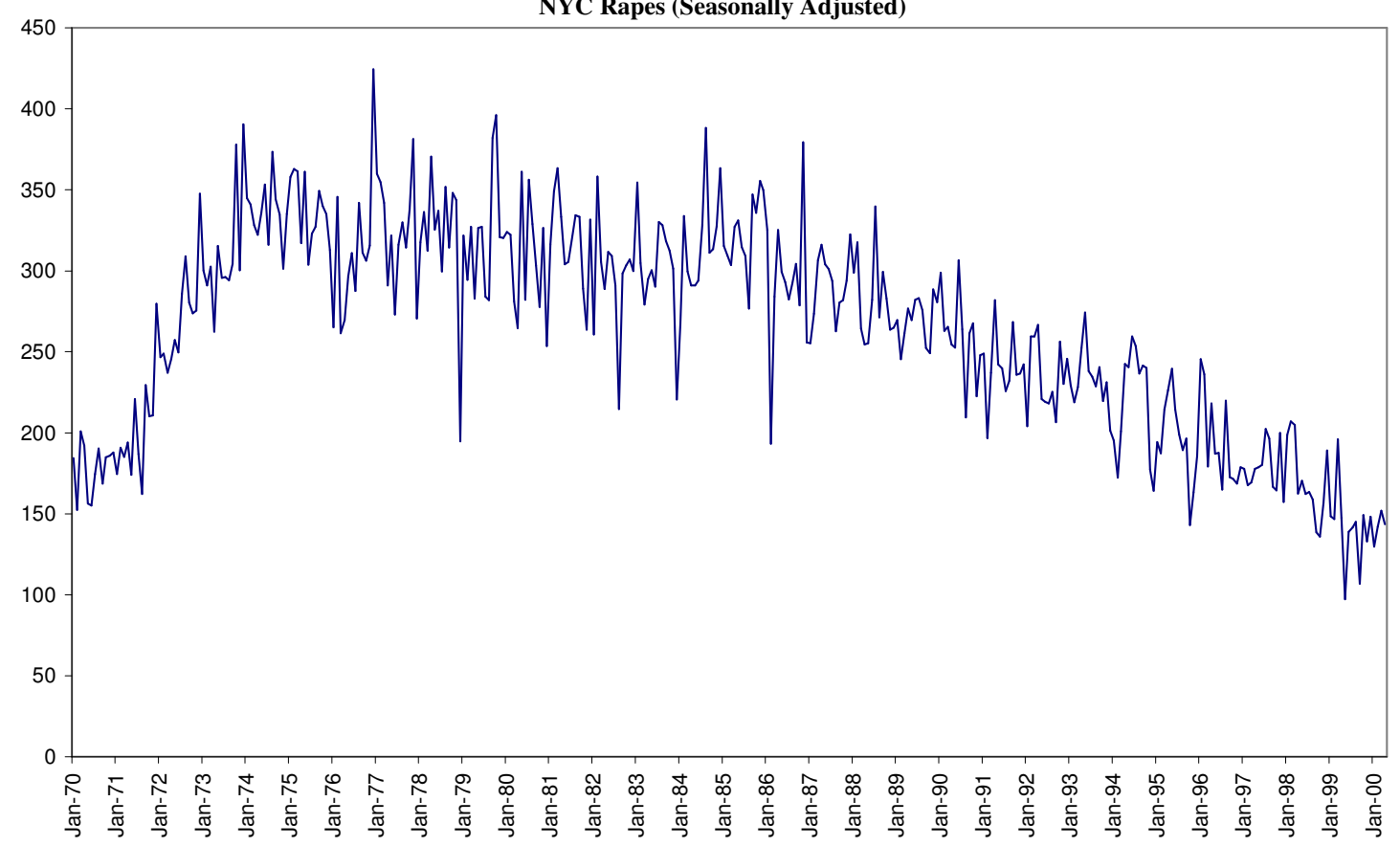


Figure 9

NYC Unemployment Rate (Seasonally Adjusted)

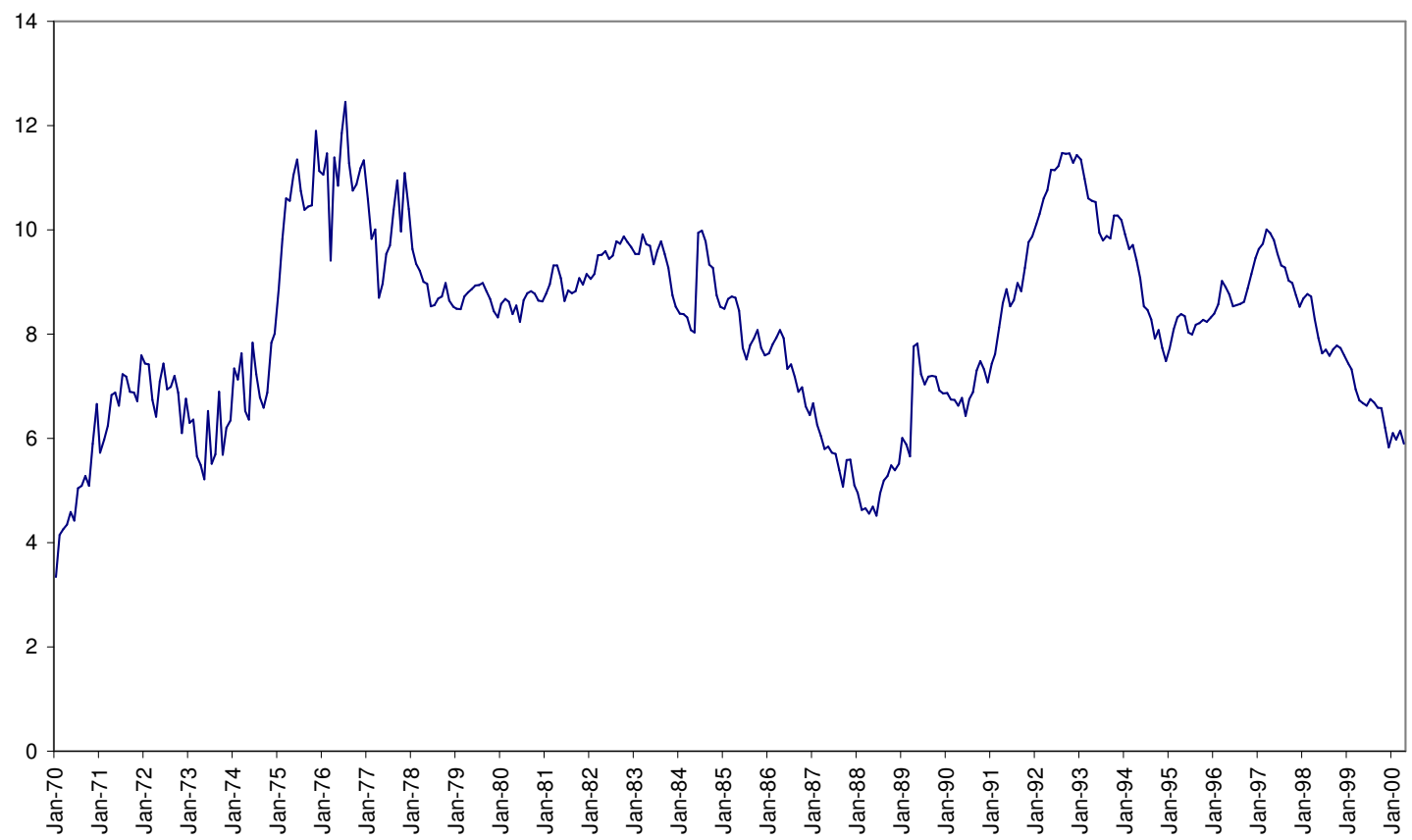

Figure 10

NYC Police Officers (Seasonally Adjusted)

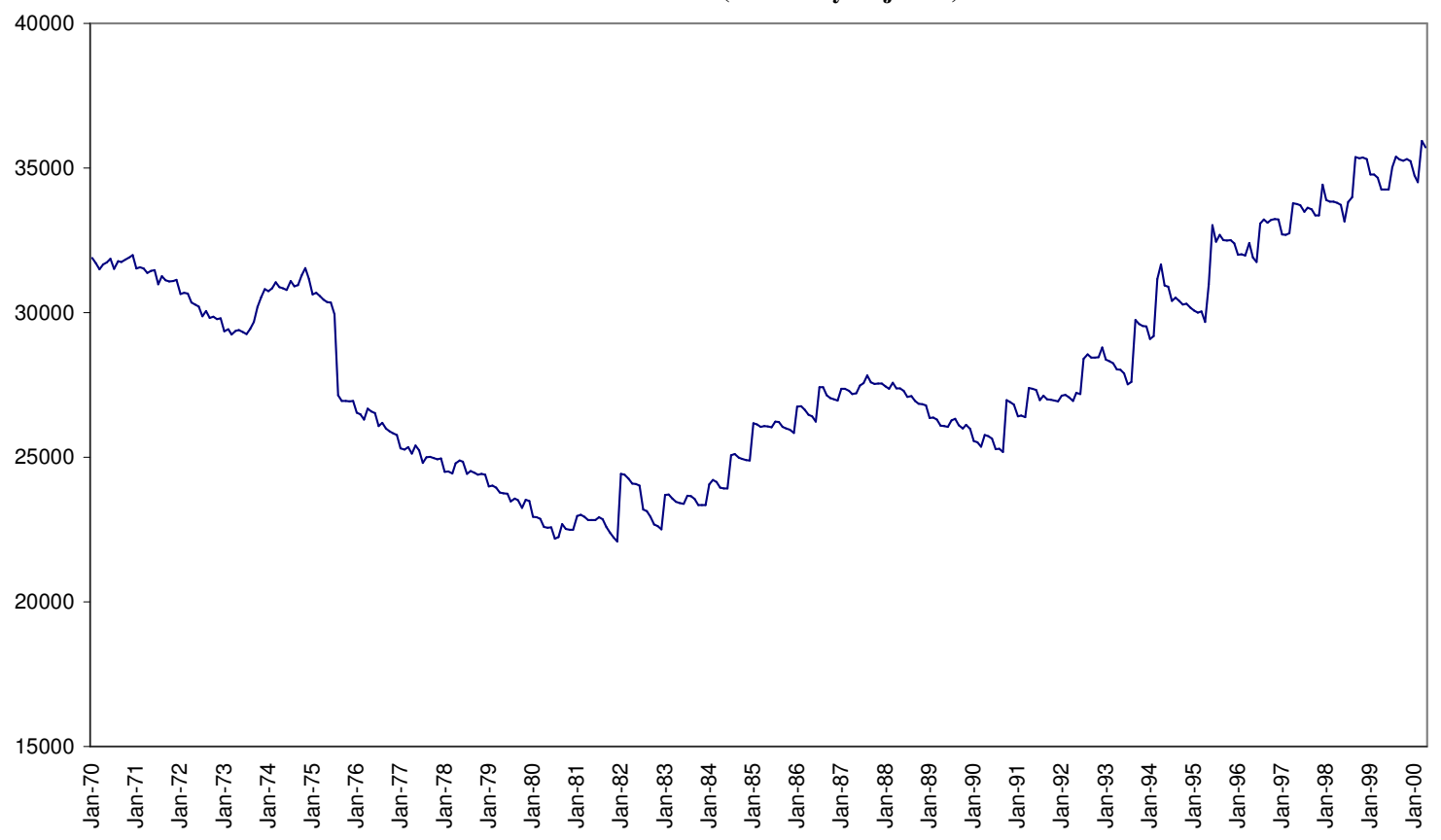

